\title{
Kıbrıs Sorunu Çözüm Sürecinde Crans Montana Görüşmelerinin Kıbrıs Basınında Haberleştirilmesi ${ }^{1}$
}

BaşvuruTarihi: 21.11.2020 Yayın Kabul Tarihi: 19.12 .2020 Yayınlanma Tarihi: 30.12 .2020

Hülya Özkoyuncu ${ }^{2}$

Girne Amerikan Üniversitesi

mdyahulya@hotmail.com

(iDORCID: 0000-0002-7477-3271

\section{Gülay Asit ${ }^{3}$}

Girne Amerikan Üniversitesi

gulayasit@gau.edu.tr

(iD) ORCID: 0000-0001-6834-8714

\section{ÖZET}

Kıbrıs sorunu Ada'daki iki toplumun olduğu kadar tarihsel süreçte bu toplumlarla bağı olan, ayrıca Ada'nın stratejik konumundan dolayı başka devletler için de çözüm isteyen bir sorundur. Bu amaçla isviçre'nin Crans Montana şehrinde yapılan çözüm süreci görüşmeleri beşli zirve şeklinde gerçekleşmiştir. Basının oldukça ilgi gösterdiği zirveye ait gelişmeler ve buna yönelik yapılan haberler bu çalışmanın konusunu oluşturmaktadır. Çalışmada nitel araştırma yöntemlerinden betimsel analiz tekniği kullanılmıştır. 20 Haziran 2017- 30 Haziran 2017 tarihleri arasında farklı görüşe sahip Afrika, Kıbrıs ve Yeni Düzen gazetelerinin Crans Montana'daki zirveye ilişkin haberleri nasıl verdiği, haber içeriklerinin nasıl oluşturulduğu analiz edilerek, haber içeriklerinde gazetelerin ideolojisinin etkisi saptanmaya çalışılmıştır. Çalışmanın sonuçlarına bakıldığında, genel olarak her gazetenin kendi ideolojisini habere yansıttığı görülmüştür. Ancak Afrika'da verilen haberlerde, haberin dilinde habercilik pratiklerinin dışına çıkıldığı, alaycı ve suçlayıcı bir üslup kullanıldığı belirlenmiştir. Ayrıca haberlerde taraflara eşit yer verilmediği de saptanmıştır.

Anahtar Kelimeler: Kuzey Kıbrıs, Crans Montana, Afrika, Kıbrıs, Yeni Düzen.

\footnotetext{
${ }^{1}$ Bu makale, Dr. Öğr. Üyesi Gülay Asit danışmanlığında Hülya Özkoyuncu tarafından 14.08 .2020 tarihinde tamamlanan "Kıbrıs Sorunu Çözüm Sürecinde Crans Montana Görüşmelerinin Kıbrıs Basınında Haberleştirilmesi" başıkılı yüksek lisans tezinden derlenmiştir.

2 Uzman. Girne Amerikan Üniversitesi.

${ }^{3}$ Doktor Öğretim Üyesi. Girne Amerikan Üniversitesi.
} 


\title{
News Reports in the Cyprus Media About the Cyprus Problem Solution

\author{
Hülya Özkoyuncu ${ }^{5}$ \\ Girne American University \\ mdya hulya@hotmail.com
}

ORCID: 0000-0002-7477-3271

Gülay Asit ${ }^{6}$

Girne American University

gulayasit@gau.edu.tr

(iD) ORCID: 0000-0001-6834-8714

\begin{abstract}
The Cyprus problem is a burning issue awaiting a solution not only for the two communities in the island but also for some other states, which have relationships with these societies in the historical process particularly due to the strategic position of the island. Therefore, the negotiation summit on the solution process took place with the participation of five states in Crans-Montana, Switzerland. This study examines the developments of the summit, which attracted considerable media attention, and the news published about the summit. The study used the descriptive analysis method which is among the qualitative research methods. Analyzing the news contents of the Afrika, Kıbrıs, and Yeni Düzen newspapers, which have different standpoints, about the summit in Crans-Montana between June 20, 2017 and June 30, 2017, this study attempts to determine the impact of ideologies of the newspapers on the news contents. Examining the results of the study, it was observed that each newspaper generally reflected its own ideology to the news. Furthermore, it was also determined that, contrary to the ordinary reporting practices, a cynical and accusatory language was used in the news reports of the Afrika newspaper. Moreover, it was determined that the parties were not given equal coverage in the news.
\end{abstract}

Keywords: Northern Cyprus, Crans Montana, Afrika, Kıbrıs, Yeni Düzen.

\footnotetext{
${ }^{4}$ This article was compiled from the master thesis titled "News Reports in the Cyprus Media About the Cyprus Problem Solution Process in Crans-Montana Negotiations Conceptualization" completed by Hülya Özkoyuncu under the supervision of Assistant Professor Gülay Asit on 14.08.2020.

${ }^{5}$ Specialist. Girne American University.

${ }^{6}$ Assistant Professor. Girne American University.
} 


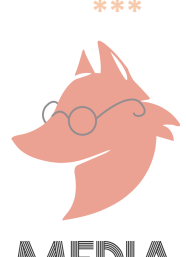

\section{Giriş}

Kitle iletişim araçlarının kamuoyu oluşumunda çok önemli etkileri olduğu yadsınamaz. Birey ve toplumları yönlendirmedeki etkinlik, dünya savaşları döneminde enformasyonun dezenformasyona dönüştürülmesinde manipüle edici haberler ve geniş çaplı propaganda ile belirginlik kazanmıştır. Nitekim medya, iletişim kurma, haber iletme fonksiyonlarının haricinde kamuoyu oluşturup, onu yönlendirerek kitleleri bir amaç ve hedef uğruna yönlendirecek konuma gelmiştir. En genel tanımıyla kamuoyu, bir konuyla ilgili halkın genel düşüncesidir (Türk Dil Kurumu7 (TDK), 2011). Kitle iletişim araçları, dünyanın her yerinde uzak ya da yakın demeden, gerçekleşen olaylarla ilgili topluma haber ve bilgiler verdikçe, kişiler medya tarafından servis edilen olgu ve olayların işlendiği bilgilerle tutumlarını şekillendirmektedir (Işık, 2008, s. 157).

Kamuoyunun oluşumuna katkı sağlayan kitle iletişim araçları hakkında Güz, tarafsız bir yayın politikası izlenmelidir, görüşünü savunur (2008, s.17). Medya dünya ve ülke gündemindeki gelişmeleri haber konusu yaparak, objektif biçimde kamuoyunun gündemine getirmeli, kamuoyunu bilgilendirmeli yorum ve eleştirileriyle de kanaatlerin oluşmasına destek vermelidir. Nitekim kitleler kararlarını, medya kuruluşlarının haberleri veriş biçimine konusuna ve içeriğine göre oluşturmaktadır. Dolayısı ile kitle iletişim araçları kamuoyunu oluştururken aynı zamanda kamuoyunu etkileyip yönlendirmektedir (Işık, 2008, s. 157).

Kitle iletişim araçlarına atfedilen olumlu ve olumsuz özellikler gerek sosyal gerek siyasal anlamda Kıbrıs sorunu ve çözüm sürecinin medya tarafından ele alınışında da tartışmaları beraberinde getirmiştir. Kıbrıs sorunu ve çözümsüzlükle sonuçlanan soruna ilişkin süreçler 1990 '। yıllardan sonra sıklıkla haberleştirilmiş, bu haberlerde sık sık propaganda içerikli popülist yayın politikaları güdüldüğü görülmüştür. Dolayısı ile siyasal aktörlerin politikalarını ve ideolojik amaçlarını belli kitlelere, gruplara, bloklara ya da ülkelere kabul ettirmek ve gerektiği takdirde eyleme çevirmek, uygulamak üzere türlü iletişim yöntem ve çeşitlerini kullandıkları görülmüştür.

Çalışmada Kıbrıs sorunu çözüm süreci kapsamında İsviçre'nin Crans Montana şehrinde gerçekleştirilen zirveyle ilgili Afrika, Kıbrıs ve Yeni Düzen'de verilen haberler irdelenmiştir. Kuzey Kıbrıs basınında, ideolojisi birbirinden farklı bu üç gazetedeki ilgili haberlerin analiz edildiği çalışmanın amacı, medya sahipliğinin ve onun ideolojisinin haber içeriğini nasıl şekillendirdiğini ortaya koymaktır. Bu amaçla 20 Haziran 2017- 30 Haziran 2017 tarihleri arasındaki 10 günlük periyotta adı geçen gazetelerin haberleri incelenmiştir. Haber başıkları ve içerikler şu sorular bağlamında irdelenmiştir:

1- Gazetelerdeki haber sayıları ne kadardır?

2- Gazetelerin manşet ve sürmanşetten verdiği haberlerin başlıkları nasıldır?

7TDK, Güncel Türkçe Sözlük Erişim Tarihi: 18 Aralık 2020 https://sozluk.gov.tr/ 


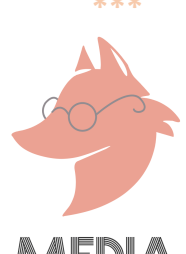

Cilt / Vol: $03-$ Sayı / No: $02 \quad$ I $\quad$ e-ISSN: 2757-6035

\section{MEDIAJ}

3- Farklı ideolojik görüşlerdeki bu gazeteler Crans Montana görüşmelerine ilişkin aynı konu başlı̆ındaki haberleri nasıl vermişlerdir?

Haberin özellikleri ve ideoloji kavramı üzerinden ele alınan çalışmada kavramlar açıklandıktan sonra, Kıbrıs sorunu ve Kıbrıs Basını hakkında genel bilgilere yer verilmiştir. Sonrasında ise nitel araştırma yöntemlerinden betimsel analiz yoluyla haber başlıkları ve içerikleri analiz edilmiştir. Analizde öncelikle gazetelerdeki haberlere ilişkin sayısal veriler frekans tablosu şeklinde verilmiş, daha sonra gazetelerin haber pratiklerinin anlaşıması için haberlerden doğrudan alıntılar yaparak betimsel analiz gerçekleştirilmiştir.

\section{Medya Haber ve İdeoloji}

Bir haberin tüm unsurlarının eksiksiz biçimde oluşturma süreci bazı önemli nitelikler göz önünde bulundurularak gerçekleşmektedir. Habere konu olan olayın gerçek bir şekilde ele alınması ve konuya bağlı kalınması gerekmektedir. Haberde konunun, sürecin, kişilerden aktarılan bilgilerin çevresi ortaya koyulmalı, olayı takip eden haberci haber içeriğini oluşturma sürecinde öznel yaklaşmamalı, ön yargıya yenik düşmemeli ve haberi olduğu gibi oluşturmalıdır. Habere konu olan taraflara eşit şekilde yer verilmeli ve haberde nesnelliğin sağlanması yapılmalıdır. Nesnellik habercinin gerçekleşen olaya mesafeli yaklaşmasıyla elde edilir. Dolayısı ile haberci habere yansız, tarafsız yaklaşmalı, konunun içinde yer almamalıdır (Aslan, 2002, s. 133).

Gazetecilikte en çok üzerinde durulan kavramlardan birisi olan tarafsızlık hem ahlaki hem de eylemsel bir içeriğe sahiptir. Bu kavram basın tarihi boyunca gerçeğe yaklaşmanın ve doğru haberciliğin bir yolu ve gazetecilik mesleğinin en yüksek ahlaki amacı olarak sunulmuştur (Atabek, 1994, s.23). Diğer taraftan gazetecinin taraf olabileceği durumlar Türkiye Gazeteciler Cemiyeti tarafından şu şekilde açıklanmıştır:

Gazeteci ve yayın organı, her ne nedenle ve her ne biçimde olursa olsun, taraf olmaları halinde bu konumlarını kamuoyuna açıkça belirtmelidir. Yayın organı yahut yorumcu, siyasi, ekonomik ve toplumsal tercihlerinin doğrultusunda yayın yapabilir. Bu durumda bu tavır açıkça ortaya konulmalı, ayrıca yorum ile haber olay ayrımı kesin biçimde yapılmalıdır.

Medya ve iletişim alanında önemli bir unsur olan ideoloji, çalışma alanlarının önemli konusu olmuştur. Bu konu hakkında günümüzde ideoloji kavramının sıklıkla dile getirilmesi ve üzerinde çalışmalar yapılmasının en önemli nedeni medyada yer alan haberleri oluşturan içerikler ve tekrar tekrar bu ideolojinin yeniden şekil alarak kitleye iletilmesidir (Devran, 2010, s. 121). Nitekim Zizek, tarihsel tahayyül ufkunun nasıl bir değişime maruz kaldığının yansıması olarak

\footnotetext{
${ }^{8}$ Ayrıntılı okuma için bkz. Türkiye Gazetecileri Hak ve Sorumluluk Bildirgesi https://www.tgc.org.tr/bildirgeler/t\%C3\%BCrkiye-gazetecilik-hak-ve-sorumluluk-bildirgesi.html (Erişim Tarihi: 8 Aralık 2020)
} 


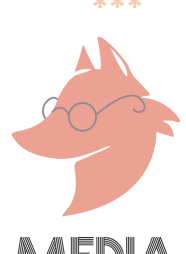

medyadaki ideoloji kavramının geçerliliğini kabul etmeye mecbur olduğumuzu öne sürmektedir (1994, s. 1).

İdeoloji teriminin Destutt de Tracy, Cabanis ve arkadaşları tarafından yaratıldığı bilinmektedir. Bu terimden anladıkları, fikirlerin (ideo-) oluşuna ilişkin teoridir (-loji); bu ikisi birleştiğinde ideoloji terimi ortaya çıkmaktadır (Althusser, 2014, s. 64). Kelimenin özgün anlamı "fikirler bilimi" dir ve "fikirlerin kökeninin araştırılması"na yönelik "fikirlerin analizi"ni ifade etmektedir. (Gramsci, 2006, s.35). İdeoloji kavramının fikirlerin rolüne doğrudan atıfta bulunduğunu ifade eden Hall, fikirlerin kendi kendine yeterli olmadığı önermesini sunmuştur. Fikri üretenlerin fikir üzerinde uyguladığı belirleyiciliğin doğası keşfedilebilirse fikirlerle ilgili merkezi bir şeyin açığa çıkabileceğini ileri sürmüştür (1977, s.10).

İdeoloji olgusuna vurgu yapan önemli isimler arasında Marx ve Engels gelmektedir. Marksizm ideolojiyi, burjuva düşüncesiyle ortaya çıkmış olumsuz çarpıtılmış sonuçları ile ele almaktadır (Hall, 1980, s.20). Marx ve diğerleri insan bilgisinin, toplumdaki değer yargılarının ve davranışlarının oluşumunu toplumdaki ekonomik ilişkilerle şekillendiğine inanmakta ve ideolojileri "aldatıcı fikirler sistemi" veya "sınıf çıkarlarına hizmet eden bir gizem oluşturma aracı" olarak görmektedir (Gee, 2008, s. 9; Marx ve Engels, 1999, s. 42).

Türk'e göre ideoloji “toplumsal yaşamdaki anlam, gösterge ve değerlerin üretim süreci; belli bir toplumsal grup veya sınıfa ait fikirler kümesi veya inanç sistemi; egemen bir siyasi iktidarı meşrulaştırmaya yarayan fikirler; sistemli bir biçimde çarpıtılmış iletişim söylem ve iktidarın çatışması"dır (aktaran Devran, 2010, s.15).

Dünyada yaşanan olaylar ve olgular bütününde bireyler, içinde yaşadığı dünyanın nasıl şekillendiği ve nasıl anlamlandırıldığını iletişim araçları aracılığı ile içselleştirmişlerdir. Kitle iletişim araçları arasında yer alan gazeteler ve televizyonlar, içinde yaşanan dünyayı bu haber içerikleri ile anlamlandırdıkları için tüm yayımlanan metinler ideolojik unsurlar taşır. Dolayısı ile olay ve olguların konuları farkııık gösterdiği bakımından ele alınacak olunursa haber içerikleri de farklı anlamlardan oluşan bir alan olarak karşımıza çıkar (Smith'den aktaran Yaylagül ve Çiçek, 2012, s.6). Devletin ideolojik aygıtlarından birisi olan haberleşme DiA'sı (basın, radyo-televizyon vb.) bu bağlamda egemen sınıfın ideolojisi olan egemen ideoloji altında, bir bütünlük sergilemektedir (Althusser, 2014, s. 51).

İdeolojiler haber oluşumu sürecinde habere konu olan her şey hakkında zengin bir dil üretir, haberi şekillendirir, kişilerin algılama dünyasına kod açacak şekilde medyaya yön verir (Selçuk ve Şeker, 2012, s. 20). Dolayısı ile medya yönlenirken, toplum ve birey, içinde yaşadığı hayatın getirdiklerinde neyi hangi şekilde ve olaylara hangi açıdan yaklaşacağı ya da bakacağı şeklinde yönlenmiş olur. Fowler (1991), haberlerle ilgili yapmış olduğu araştırmada, toplumun değer yapısını oluşturan göstergebilimsel kodlara nüfus eden dil yapısına vurgu yapar. Habere konu 


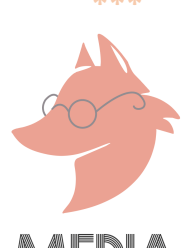

olan olaylar farklı bir dil ve söylemle anlamlı kılınabilir ancak söylemi oluşturan ana kriterler bireyin ideolojisi, hayat tarzı ve kültürü, iletici aracının konumu, bu aracın ideolojik yapısı hedef kitlenin kendine özgü kriterlerdir. Dolayısı ile içinde yaşadığımız dünya düşünce bağlamında ideoloji oluşumunda değer ve inançlarda farklı yansımalarla anlamlandırııı. Bu bağlamda kitle iletişim araçlarından aktarılan ve yayımlanan haberlerdeki dil, kendisine yüklenen söylemler aracılığı ile anlamları alıcıya iletir. Ve tarafsız bir araç olmayıp inşa edici bir araç olma özelliği taşır. Haber oluşturan metinler, hâkim olan düşünceler anlatı yoluyla, egemen düşünceyi ön plana çıkartarak, belirli dünya görüşlerini barındıran ideolojik metinlere dönüşür (Bulut ve Yaylagül, 2004, s.124).

İdeolojinin var olması, haber metinlerinin düzenlenmesi ile ortaya çıkar. Haberi oluşturan metinler bazı değerlere göre oluşum gösterir, toplumun kültürel kodları tarihsel dönemi siyasi ve ekonomik koşulları altında oluşur. Belirlenen değerler çevresinde üretilen haberler ham bilgiler olarak ele alınır, sonrasında bazı siyasi ve teknik işlemlerden geçerek yayınlanır. Bu bağlamda haberin oluşturulmasında muhabirin ve medya sahipliğinin ideolojik yanlılığı önemli rol oynar. Dolayısı ile haber, siyasi değerler ve söylemlerden bağımsız bir şekilde oluşamaz. Bu bağlıık haberciye bazı sınırlandırmaları da beraberinde getirecektir. Dolayısıyla haberi oluşturma süreci ideolojik bir yapı sürecidir. (Mc Cullagh'dan aktaran Yaylagül ve Çiçek, 2012, s. 6).

Karaduman'a göre haber medyası egemen ideolojinin söylemlerini taşır (2009, s.26). Bu noktada medya oldukça işlevsel bir öneme sahiptir. Medya haber metinlerindeki anlatımıyla bilerek ya da bilmeyerek çoğunluğun rızasının kendiliğinden oluşmasına katkı koyar. Dolayısı ile haber içindeki metinleri oluşturan mesajlara ulaşmak, okumak ve çözmek egemen ideolojinin kolaylıklarına ulaşmanın bir yoludur. Burton'ın belirttiği üzere medya kurumları haberleri inşa etme sürecinde kendi ideoloji ve inançlarını ön plana koyarak, toplumdaki beklenti ve çıkarlarına göre haber olacak konuyu metin haline getirirler (1995, s.46).

Medya kurumları kendi çıkarları doğrultusunda kendi ideolojileri ile inşa ettiği haberleri tarafsız yayınlamaz (Vural, 2010, s. 104). Egemen ideolojinin söylemlerini tekrar tekrar üreterek alıcıya iletirler. Diğer bir durumda farklı medya kuruluşları aynı haberleri farklı içerik ve söylemlerle işler ve yayımlar. Dolayısı ile toplumu ilgilendiren konuların haberleştirilme aşamasında, gerçeklik içerikle tekrardan kurgulanır, söylem haline gelir. Bu bağlamda söylem, metin inşası, görüntü kayıtları, kurgunun oluşmasında ve iletilmesinde kendini göstermektedir. Egemen güçlerin etkisi ile oluşan haber egemen gücün ideolojilerini yansıtır. Herhangi bir haberin oluşum sürecinde bu etki eden ideolojinin haber haline getirilmesi ve oluştuğu andan itibaren belirli bir sistem içinde düzen ve sıralaması söylemi oluşturur (Orhon, 2004, s. 45).

\section{Kıbrıs Sorunu Çözüm Süreci ve Yazılı Basın}

Kıbrıs sorunu geçmişten günümüze kadar devam eden ve güncelliğini hiçbir zaman kaybetmeyen 


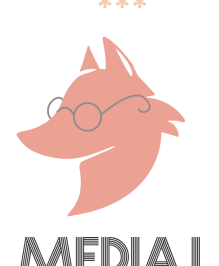

uluslararası bir meseledir. Hala çözümü bulunamayan bu sorunun sebebi; jeopolitik ve jeostratejik konumundan dolayı başka ülkelerin de Ada'ya önem vermesidir. $A B D$, İngiltere, $A B$ gibi küresel güçlerin Ada'yı önemsemesinin nedeni, Doğu Akdeniz' de deniz hâkimiyetini sağlayan stratejik bir liman ve güvenlik açısından askeri üs olarak kullanılabilecek stratejik mevki görevi görmesidir. Kıbrıs meselesi Türk ve Yunan dış politikasının en önemli sorunsalıdır. Ada'da yaşayan iki halk arasındaki sorunu çözebilmek için garantör devletlerden Türkiye ve Yunanistan'ın çabaları günümüzde de devam etmektedir (Bozkurt ve Demirel, 2004, s. 93).

Ada tarihinde 1571'de Osmanlı Devleti'nin Kıbrıs'ı fethetmesiyle Ada üzerinde hukuki anlamda Türk egemenliği kurulmuştur. Bu egemenlik kesintisiz 307 yıl kadar süregelmiştir. (Vatansever, 2010, s. 1490). 1770 yılında yani XVIII. Yüzyııın ikinci yarısında Mora isyanı olarak bilinen ağır bir isyan ortaya çıkmış, Yunan "Megali İdea" fikri ortaya atılmıştır. "Megali İdea" fikri sadece Yunanistan Krallığı içinde yaşayan Yunanlıları değil, dünya üzerinde yaşayan tüm Yunanlıları da içine alacak şekilde bir kapsama sahip olmuştur (Kalelioğlu, 2008, s. 108).

Kıbrıs adası 1878 yılında Osmanlı Devleti tarafından İngiltere'ye verilmiştir. Yıl 1923'te Lozan antlaşması imzalanmıştır. Lozan Antlaşmasının 16. Maddesi Türkiye açısından ağır bir antlaşma olup, Türkiye'nin Kıbrıs ve diğer adalar üzerindeki her türlü hakkından ve sıfatından vazgeçeceği ve adaların geleceğinin ilgililerce düzenleneceği belirtilmiştir.

Bu durumda Türkiye, adayla ilgili hiçbir söz hakkına sahip olamayacaktı. Bu sebeple, Türk delegesi 16. maddenin bu kısmına itiraz etti ve bu kısmın madde metninden çıkarılmasını sağladı. Böylece Türkiye, Lozan Antlaşmasının yürürlüğe girmesinden sonra, 16. maddede sözü edilen ilgililerden biri olarak, Kıbrıs'ın geleceği konusunda söz sahibi olacağını saklı tutmuş oldu (Vatansever, 2010, s. 1496).

Kıbrıs adası fiilen 1878 ' de ve resmen 1923 'te İngiliz idaresi altına girmiş ancak Kıbrıs sorunu buna rağmen varlığını korumuştur. 1959'a gelindiğinde Rumların, kendi istekleri doğrultusunda Ada'nın statüsünü değiştirmek için birçok faaliyet yürüttükleri görülmüştür (Kalelioğlu, 2008, s. 110). “Kıbrıs Türk halkının Enosise karşı verdiği mücadele, 1960 öncesinde Ada'nın Yunanistan'a bağlanmasını engellemiş ve bağımsız Kıbrıs Cumhuriyeti'nin kurulmasını sağlayan en önemli faktör olmuştur" (Vatansever, 2010, s. 1499). Nitekim Kıbrıs Türk basınının Enosis hareketine karşı yıllarca uğradıkları şiddet ve eylemlere karşın haklı müdafaasını dünyaya duyurmak için ortaya çıktığı bilinmektedir. "Kıbrıs basını bu hareketin önüne bir duvar örmek ve Türk toplumunun sesini dünyaya duyurmak için mücadele amaçlı bir çizgiye sahip olmuştur" (Asit, 2019, s.327). Nitekim ilk gazeteler İngiliz yönetimi altındaki Ada'da $1880^{\prime}$ li yıllarda yani Enosis hareketinin yükselişe geçtiği dönemde yayımlanmaya başlamıştır. İlk Türk gazetesi Saded 11 Temmuz 1889 tarihinde, ikinci gazete Zaman gazetesi 1891 yıında yayın hayatına başlamışır. Bu milli gazetelerin var olma nedeni Kıbrıs sorununda Kıbrıslı Türklerin meşru müdaafası ve haklılığını savunarak; 
-Ingiliz sömürgeciliğiyle savaşmak,

-Kıbrıs sorununda Rum görüşlerinin propagandasını yapan çok sayıdaki Rum gazetesiyle mücadele etmek,

-Enosis hareketine karşı durmak,

-Kıbrıs Türk görüşlerini dünyaya duyurmak,

-Türkçe'nin Kıbrıs adasında yaşamasını sağlamak,

-Adadaki Türk toplumuna toplumsal, siyasal, ahlaki ve eğitimsel açılardan yardımcı olmak, amacındadır (Azgın, 1998, s. 642).

Bu tarihlerden günümüze kadar yayın hayatına başlamış yayın hayatına son vermiş ve halen de devam eden gazetelerin ortak noktası, Kıbrıs Türkü’nün mücadele basını olma özelliğidir. Bu ortak noktayı İsmail Bozkurt şöyle açıklamaktadır: "Gazetelerin yayın ilkeleri ve izledikleri yayın politikaları incelendiğinde görülecektir ki, tüm gazeteler bir işlevi yerine getirmek için yayınlanmıştır" (aktaran İrvan, 2006, s.3).

Uzun yıllar süren Kıbrıs sorunu ve çözüm süreci bağlamında 1960 yılında iki tarafı bağlayan Bağımsız Kıbrıs Cumhuriyeti kurulmuştur (Yeni Şafak, 2017). Kıbrıs Cumhuriyeti devleti bağımsız olarak Kıbrıs Sorununa çözüm getirmeye yönelik ilk adımlardan birisi olmuştur. Ancak Kıbrıslı Rumların anayasasında Türklere tanınan hak ve özgürlüklerle ilgili kısıtlama getirilmiş eşit ayrıcalıklar tanınmamıştır. Bu durum Ada'da güvensizliği beraberinde getirmiş hukuk eksikliği dolayısı ile şiddete yol açmıştır. (Sandıklı ve Erdem, 2017, s. 211).

Ada'nın homojen yapısı mevcut olmadığı için 1960 yılı anlaşmaları ile etnik yapının üzerinde durulması gerektiği göz ardı edilmemelidir. "Kıbrıs Türkü ve Kıbrıs Rum halkının yaşayışözellikleri ve savunduğu haklar göz önüne alınarak federal sisteme dayalı devlet yönetimi müttefik ülkeler arası anlaşma ile inşa edilmekteydi. Bu bağlamda ortak coğrafi alanlarda yaşıyor olmaları topluluk halinde yaşama düzenini ortaya çıkartmakta bu nedenle de federal sistem yönetimi ortadan kalkmaktaydı (Tezel, 2008, s. 64).

Kanlı Neol olarak bilinen 1963, Aralık 21 ve 22 tarihlerinde Türklere karşı başlatılan silahlı saldırılar olmuştur. Bu silahlı saldırılar Ada'da yaşayan iki toplumun çatışmalarını fitillemiş, önceleri otuz köy olmak üzere 103 köy saldıılarda acı kayıplar vermiştir (Stephen, 1997, s. 32). "Kanlı Noel" eylemleri yerleşik hayatta yaşayan Rumlar ile Türkler arasında çatışmaların ayyuka çıktığı ve sorunların çı̆̆ gibi büyüdüğü bir olay olmuştur.

1964 yılı sonrası devam eden şiddet esaret ve eylemler Kıbrıs Adasında varlık gösteren Türkleri çaresiz bırakmıştır. 1967 yılında da tekrar büyük sıkıntılar yaşanmış, şiddet ve saldırılar sonucunda Türkiye Adaya çıkarma yapma kararı almıştır. 15 Temmuz 1974'te Nikos Sampson darbesi ile Enosis'e yani büyük bir Yunanistan kurma hayaline Türkiye'nin Kıbrıs Barış Harekâtı ile son verilmiştir (Kalelioğlu, 2008, s. 112). Türkiye'nin 20 Temmuz 1974'te Ada'ya askeri müdahalede bulunmasına dünya büyük bir tepki göstermemiştir. Çünkü 1974 Kıbrıs Barış 


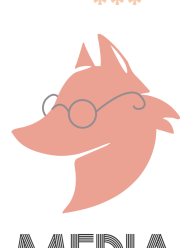

Harekâtı Türkiye'nin meşru hakkı olarak görülmüştür. (Vatansever, 2010, s. 1506).

Kıbrıs barış harekâtları ile Ada'da yaşayan Türkler büyük oranda huzur bulmuş can ve mal güvenliğini sağlamıştır. Barış Harekâtı sonrası Kıbrıs Türk Federe Devleti 13 Şubat 1975'te kurulmuş olup, beraberinde nüfus mübadelesi yapılmıştır. Sözü edilen "elli üyeli bir kurucu meclisin hazırladığı anayasa 8 Haziran'da yapılan bir referandumla kabul edilmiş ve 17 Haziran 1975'te Kıbrıs Türk Federe Devleti Resmî Gazetesinde yayınlanmıştır" (Arık, 2011, s. 20).

Kıbrıs Barış Harekâtı sonrası İsviçre'nin Cenevre kentinde bir konferans düzenlenmiş, bu konferansa Türkiye, İngiltere ve Yunanistan'ın Dışişleri Bakanları katılmıştır. (Vatansever, 2010, s. 1515). Konferansta Kıbrıs sorununda bir ilerleme kaydedilmemiştir. Daha sonra, 8-12 Ağustos 1974 'te çözülemeyen ve devam eden bu sorunlar için 2. Cenevre Konferansı yapılmıştır. Ancak bu konferanstan da olumlu bir sonuç çıkmamıştır (Arık, 2011, s. 18).

15 Kasım 1983 tarihinde ise Kuzey Kıbrıs Türk Cumhuriyeti kurulmuştur (Yeni Şafak, 2017). KKTC'nin 27 yıllık siyasi yapısında beş Cumhurbaşkanı görev yapmıştır. Bunlar, Rauf R. Denktaş ve sonrasında göreve gelen Mehmet Ali Talat, Derviş Eroğlu, Mustafa Akıncı ve Ersin Tatar'dır. Kıbrıs sorunu tüm cumhurbaşkanları döneminde devam etmiştir. Ayrıca, Türkiye'nin en önemli siyasi politikaları arasında yer almıştır. Türkiye ve Yunanistan arası yaşanan bu gerilim ve çözümsüzlük süreci Türkiye $A B$ süreci gelişim ilişkileri konusunu da olumsuz yönde etkilemiştir (Öksüz, 2007, s.75).

Kıbrıs Sorunu ve Çözümsüzlük süreci Ocak 2002'de KKTC Cumhurbaşkanı Rauf R. Denktaş ve GKRY Lideri Glafkos Klerides ile ikili görüşmeler başlamış, 11 Kasım 2002 tarihinde BM Genel Sekreteri Kofi Annan, "Kıbrıs Sorununa Kapsamlı Çözüm Temeli" Annan Planını sunmuştur. Ardından 24 Nisan 2004 yılında plan referanduma sunulmuştur. Bu plan KKTC tarafından \%65'e ulaşan "evet" oyları ile kabul edilirken, Rum taraftarları tarafından \%75,8 ile hayır denmiş ve reddedilmiştir (Altan Bayraktar, 2015, s.20).

Yıllarca süregelen Kıbrıs sorunu ve Çözüm sürecinde Kıbrıs Türkleri her daim kamuoyu karşısında olumlu duruş sergilemişlerdir. Her defasında Güney Kıbrıs toplumu ve siyasi yandaşları ise uluslararası arenada olumsuz tutum sergilemişlerdir. Uzun zamandır süregelen ve çözüm bekleyen Kıbrıs Sorunu 2017' de İsviçre'nin Crans Montana şehrinde 5 li zirve adında tekrar gündeme gelmiş, BM ve garantör devletlerin katılım gösterdiği bu büyük toplantı tekrar çözümsüzlükle sonuçlanmıştır (Atun, 2018).

Gazeteler, Kıbrıs sorununun çözümüne ilişkin savundukları siyasi söylemler çerçevesinde üç kategoriye ayrılabilir: Kıbrıs Türkünün ayrı ve bağımsız olarak varlığını Kuzey Kıbrıs Türk Cumhuriyeti çatısı altında sürdürmesini ve ulusal birliği sağlamasını savunan ve 'Sağ' politik söylemi benimsemiş gazeteler; Kıbrıs Türkleri ve Rumlarının Kıbrıs adasında bir araya gelerek 


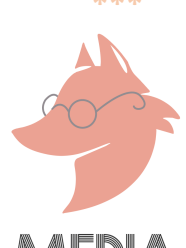

varlığını sürdürmesini ve Avrupa Birliği'nde yer almasını savunan ve 'Sol' politik söylemi benimsemiş gazeteler; kendilerini ne 'Sağ' ne de 'Sol' görüşe yakın olarak gören gazeteler ( Kitle iletişim Dergisi, 2006).

Günümüzde Kuzey Kıbrıs'ta yazılı basın olarak Afrika, Detay, Diyalog, Güneş, Haberal Kıbrıslı, Haberatör, Haberci, Hakikat, Halkın Sesi, Havadis, Kıbrıs, Kıbrıs Manşet, Kıbrıs Postası, Radikal, Star Kıbrıs, Vatan, Volkan, Yeni Bakış ve Yeni Düzen gazeteleri bulunmaktadır. Güneş Ulusal Birlik Partisinin, Ortam Toplumcu Kurtuluş Partisinin, Yeni Düzen Cumhuriyetçi Türk partisinin, Sözcü Özgürlük ve Reform Partisi'nin ideolojik söylemlerine hizmet eden siyasi gazetelerdir. Diğer gazeteler ise kendilerine yakın buldukları siyasi partilerin ideolojilerine göre yayın hayatına devam etmektedir (Polat, 2010, s. 90).

\section{YÖNTEM}

Çalışmada nitel araştırma yöntemlerinden betimsel analiz kullanılmıştır. Nitel araştırma insanların yaşam tarzlarını, öykülerini, davranışlarını, örgütsel yapıları ve toplumsal değişmeyi anlamaya dönük bilgi üretme süreçlerinden biridir (Strauss ve Corbin, 1990, s. 41).

Nitel verilerin analizinde kullanılan analizlerden biri olan betimsel analiz ise içerik analizine göre daha yüzeysel bir analiz olup genellikle kavramsal yapının önceden açık bir şekilde belirlendiği araştırmalarda kullanılır. Bu analizde elde edilen veriler, önceden belirlenen temalara göre özetlenir ve doğrudan alıntılara sık sık yer verilerek yorumlanır (Yıldııım ve şimşek, 2011, s. 40)

Çalışmanın evreni Kuzey Kıbrıs yazılı basınında günlük olarak yayımlanan basılı gazetelerde yer alan Crans Montana görüşmelerine ait haberlerdir. Çalışmanın örneklemi ise bu gazetelerden Afrika, Kıbrıs ve Yeni Düzen'de yer alan haberlerdir.

Afrika, Kıbrıs Türk toplum yapısı ve kimliğine dair yaptığı haberler ve mevcut düzen karşıtı yapısı ile Kuzey Kıbrıs'ta alternatif medya kapsamında yer almaktadır. Afrika gazetesi düşük tirajlı olup, politik görüş olarak, iktidar ve düzen karşıtı olan bir gazete konumundadır. Kıbrıs ise Kuzey Kıbrıs'ın en yüksek tirajlı gazetesidir. Yayın politikası 'doğru ses, doğru söz, doğru haber" dir. Gazete hiçbir siyasi görüşten yana olmayıp tüm görüşlere sayfalarında yer vermektedir ve basında çoksesli, çoğulcu ve katılımcı demokrasinin gereğini savunmaktadır (KIBRIS, 11 Temmuz 2018). Özel bir medya grubunun yayını olan Kıbrıs gazetesinin toplumun geneline hitap eden bir yapısı bulunmaktadır ve en yüksek tirajlı gazete olma özelliğini korumaktadır. Bununla birlikte aynı zamanda gündemi belirleyen bir gazete konumundadır (Ceylanlı ve Kanlı, 2020, s. 246). Yeni Düzen 1975 yılında Cumhuriyetçi Türk Partisi tarafından kurulmuş bir parti gazetesidir ve "barış gazeteciliği"ni benimsemiştir (http://www.yeniduzen.com/yeniduzen-gazetesi-yayin-ilkeleri8s.htm). 


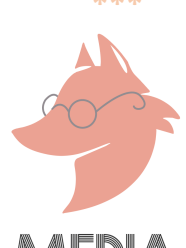

Illgili gazeteler, Crans Montana görüşmeleriyle ilgili öncesinde ve süreç boyunca çok sayıda haber yapmışlardır. Bu bağlamda görüşmelerden üç gün öncesinden başlayarak yani 20 Haziran 2017 ile 30 Haziran 2017 tarihleri arasındaki 10 günlük periyotta verilen haberler analiz edilmiştir. Bu haberlerin, ilk sayfada yer alan, manşet ve sürmanşetten verilenleri analize tabi tutulmuştur.

Araştırmada verilerin toplanması için nitel araştırma yöntemlerinden dolaylı gözlem (veri toplama) yöntemi olan kaynak taraması yöntemi kullanıımıştır. Bir araştırmada yazılı kaynaklar, araştırma konusunda verilere ulaşılabilmek için en sık başvurulan kaynaklardır (Aziz, 2017, s.73).

Verilerin toplanmasında örneklem dahilindeki üç gazetenin ilgili zaman aralığındaki 10 günlük yayımlamış oldukları gazeteler Milli Arşiv'de taranmış, konuyla ilgili haberler fotoğraflanarak toplanmıştır. Haberler daha sonra gazetenin hangi sayfalarında yer aldıklarına bakılarak sınıflandırılmış, bunlardan ilk sayfada olanlar betimsel analize tabi tutulmuştur. Bu bağlamda haber başlıkları ve haber içerikleri ayrı ayrı incelenmiştir. Başlıklarda kullanılan puntoların büyüklüğü-küçüklüğü, ayrıca başlığın büyük-küçük harflerle yazılıp yazılmadığı haber metnindeki ifadelerin olumlu-olumsuz oluşu dikkatle değerlendirilmiştir. Haber içeriğinde konunun taraflarına yer verilip verilmediği, haberde bu taraflarla ilgili kullanılan ifadelerin objektif olup olmadığı dikkate alınmıştır. Mevcut durumu anlamak için bu unsurlar göz önüne alınarak Crans Montana görüşmelerine ilişkin ilgili haberlerin nasıl betimlendiği anlaşılmaya çalışılmıştır.

\section{Bulgular ve Analiz}

Araştırmada ilgili zaman aralığında Afrika, Kıbrıs ve Yeni Düzen'de yayımlanan toplam haber sayısının 218 olduğu belirlenmiştir.

Tablo1. Afrika, Kıbrıs ve Yeni Düzen'de Crans Montana Görüşmeleriyle ilgili Çıkan Haber Sayıları

\begin{tabular}{|c|c|}
\hline Gazete Adı & Haber Sayısı \\
\hline Afrika & 60 \\
\hline Kıbrıs & 65 \\
\hline Yeni Düzen & 93 \\
\hline TOPLAM & 218 \\
\hline
\end{tabular}

Tablo 1'de de görüldüğü üzere ilgili aralıkta Yeni Düzen 93 haber yayımlarken, Kıbrıs 65, Afrika ise 60 haber yayımlamıştır. Bu haberler hem ilk sayfada hem de iç sayfalarda yayımlanan haberlerdir. 
Tablo2. Afrika, Kıbrıs ve Yeni Düzen'de Crans Montana Görüşmeleriyle Ilgili Çıkan Manşet ve Sürmanşet Haber Sayıları

\begin{tabular}{|c|c|c|}
\hline Gazete Adı & Manşet Haber & Sürmanşet Haber \\
\hline Afrika & 4 & 6 \\
\hline Kıbrıs & 1 & 15 \\
\hline Yeni Düzen & 2 & 9 \\
\hline TOPLAM & 7 & 30 \\
\hline
\end{tabular}

Tablo 2'de ise ilgili gazetelerin birinci sayfalarında yayımladığı manşet ve sürmanşet haberlerin sayısı yer almaktadır. En fazla manşet haberin Afrika'da, en fazla sürmanşet haberin ise Kıbrıs'ta yayımlandığı görülmektedir.

\section{Afrika'da Manşet ve Sürmanşetten Verilen Haberlerin Analizi}

Afrika'nın manşetten verdiği haberlere ilişkin başılklar aşağıdaki tabloda görüldüğü gibidir.

Tablo 3. Manşet Haber Başlıkları

\begin{tabular}{|c|l|}
\hline Haberin Tarihi & \multicolumn{1}{c|}{ Haber Başlığı } \\
\hline 26 Haziran 2017 & Zorla Zirve \\
\hline 28 Haziran 2017 & Hade Hissa \\
\hline 29 Haziran 2017 & Henüz uzlaşı yok Kavga da yok \\
\hline 30 Haziran 2017 & TC'liler için 4 özgürlük şartını ortaya koydu \\
\hline
\end{tabular}

Tablo 3'te de görüldüğü gibi 20- 30 Haziran 2017 tarih aralığında dört tane manşet haber görülmektedir. 20, 21, 22, 23, 24, 25 Haziran 2017 tarihlerinde manşet habere yer verilmemiştir.

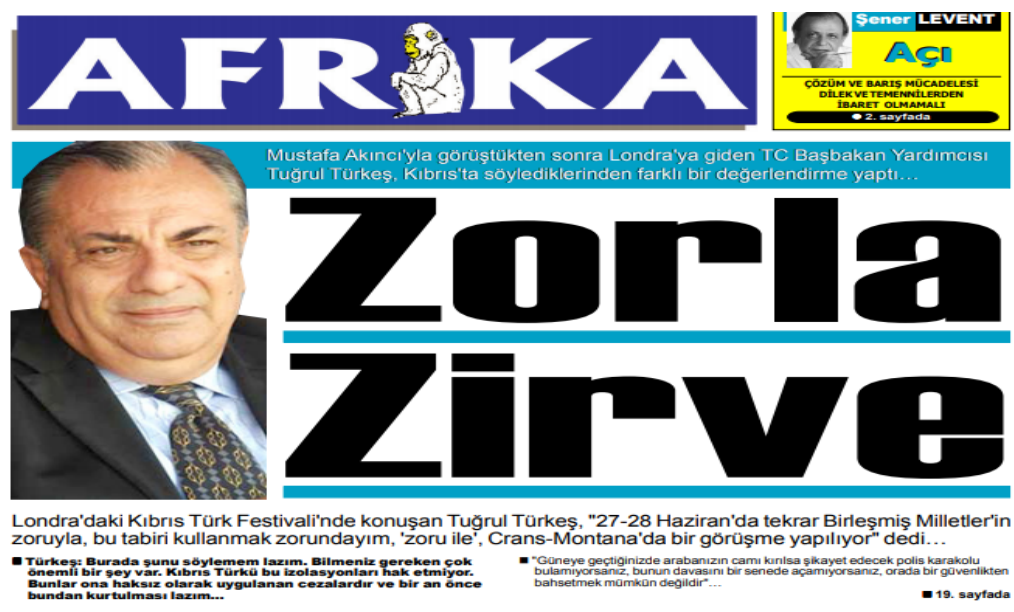

Şekil 1. Afrika'nın 26 Haziran Tarihli Manşet Haberi 
26 Haziran 2017 tarihli gazetenin ilk sayfasında iri puntolarla yazılmış olan "Zorla Zirve" haber başlı̆ıında, o dönemdeki T.C Başbakan yardımcısı Tuğrul Türkeş tarafından, "Rumlara taviz verildiği, Kıbrıs Türk'ünün izolasyonları hak etmediği zirvenin BM tarafından gerçekleştiği" dile getirilmektedir. Haberin üst başlığında ise "Mustafa Akıncı'yla görüştükten sonra Londra'ya giden T.C. Başbakan Yardımcısı Tuğrul Türkeş, Kıbrıs'ta söylediklerinden farklı bir değerlendirme yaptı" ifadelerine yer verilmiştir. Bu ifadelerden yola çıkarak incelenen manşet haberinde, Crans Montana Zirvesi'nin Birleşmiş Milletler zoru ile "zorlu” imasını vurgulayarak Güney Kıbrıs'ın pek de barış yanlısı olarak istekli olmadığı, çaba göstermediği, bu zirveyi umursamadığına dikkat çekilmiştir. Haberin devamında, Türkeş'in söylemleri incelendiğinde; Kıbrıs Türkünün halen izolasyonlara maruz kaldığını, haksız bir cezalandırma içinde olduğunu ve bir örnek göstererek “Güney Rum'a gidildiğinde arabanızın camı kırıldığında, şikâyet için herhangi bir polis ya da bir karakol bulamıyorsunuz, arabanız soyulduğunda davanızı 1 yılda açamıyorsunuz. Bunların çözülmesi gerekir" açıklaması ile BM ve zirveye katılan arabuluculara yönelik sitemkâr ifadelere yer verildiği söylenebilir.

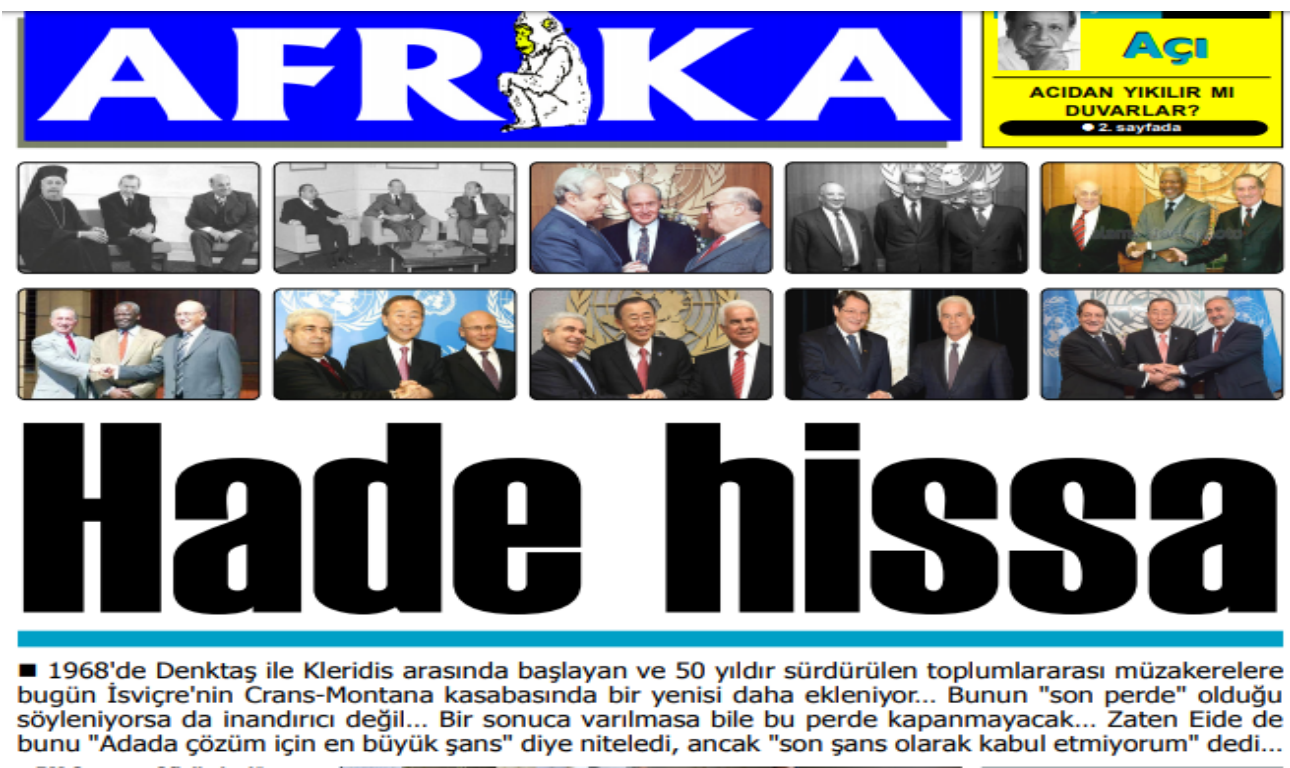

Şekil 2. Afrika'nın 28 Haziran Tarihli Manşet Haberi

28 Haziran 2017 tarihli gazetede "Hade hissa" manşeti ile yer alan haberde 50 yıldır yapılan Kıbrıs sorunu görüşmelerine Crans Montana zirvesi ile bir yenisinin eklendiğine vurgu yapılmaktadır. Görüşme "son perde" olduğunun dile getirildiğini ifade eden gazete açıklamayı inandırıcı bulunmamaktadır. Bir sonuca varılmasa dahi perdenin kapanmayacağı söylemlerine yer verilerek, müzakere için masada yerini alan arabulucu devlet yetkililerin el tokalaşma ve yüz ifadelerindeki o belirgin gülümseme çözümü destekler ve barış isteme yönünde atılmış adımların fotoğraf karesine yansımaları denilebilir. Ayrıca, "Adada çözüm için en büyük şans", ancak "son 


\section{MEDIAJ}

şans olarak kabul etmiyorum" diyen Eide'nin ifadeleri üzerinden beklenti dolu ve olumlu bir tutum sergilenerek umutların tükenmediği kanısına varılabilir.

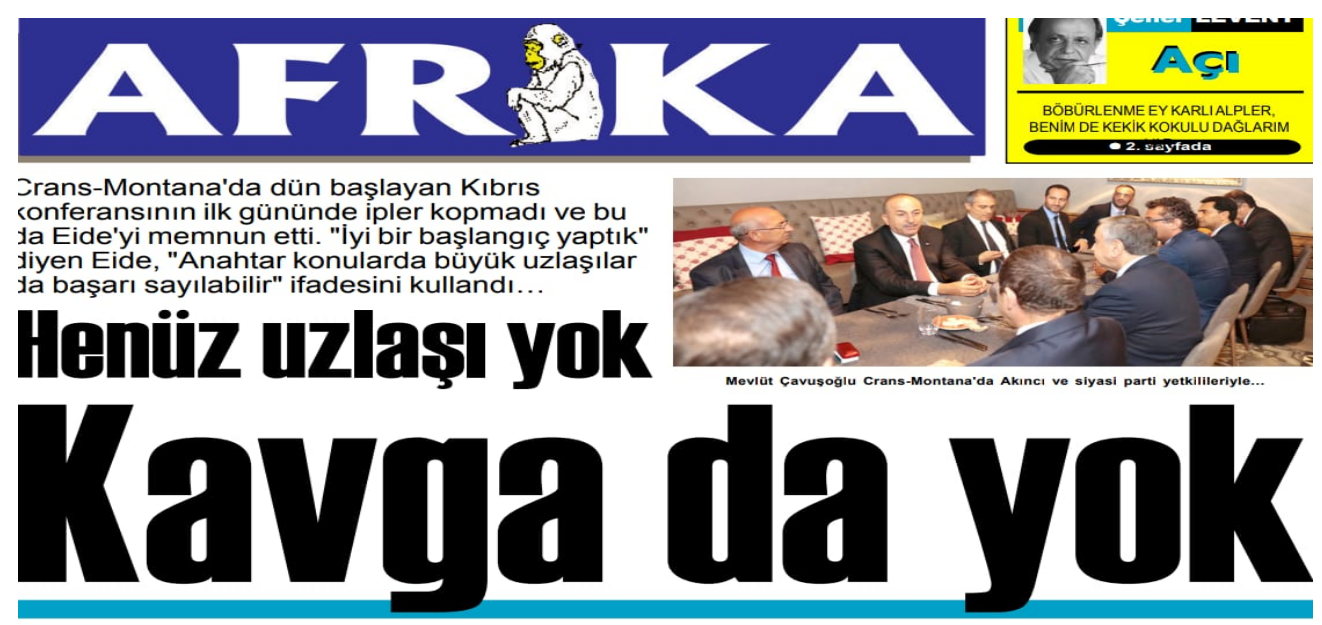

<atı duruşuyla bilinen Yunan Dışişleri Bakanı Kotzias bu kez keyifli göründü. Toplantının başında Mevlüt Çavuşoğlu'na akılan Kotzias, "Mevlüt, yarın Yunanistan'da hava $\mathbf{4 3}$ derece olacakmış" dedi. Çavuş̧oğlu'nun buna karşılık "Nikos, c ı̈̈zden hiçbir yere gitmeden burada masada olman gerekiyor" yanıtını vermesi salondakileri güldürdü.

Mustafa Akınci konferans salonuna girerken basın
mensuplarına hitaben Türkce, Rumca ve Ingilizce olarak üc dilde "merhaba" dedi...

Şekil 3. Afrika'nın 29 Haziran Tarihli Manşet Haberi

29 Haziran 2017 tarihli "Henüz uzlaşı yok Kavga da yok" haber manşetinde Kıbrıs sorunu ile garantör ülkeler ve aynı zamanda arabuluculuk yapan devletler ve yetkililer arasında negatif bir tutum sergilenmediği ve Türkiye, Kuzey Kıbrıs ve Güney Rum kesimi yetkililerinin zirvede karşılıklı olumlu konuşmaları ön plana çıkarılmıştır. "ìi bir başlangıç yaptık" diyen Eide "Anahtar konularda büyük uzlaşılar da başarı sayılabilir" ifadesine yer verilerek, taraftarların zirvedeki konulara çözüm odaklı uzlaşı istekli tutumları habere taşınmıştır.

Aynı haberin devamında zirve başlangıcı Mevlüt Çavuşoğlu'na espiri ile yaklaşan, Kotzias, "Mevlüt, yarın Yunanistan'da hava 43 derece olacakmış" demesi Çavuşoğlu'nun buna karşılık olarak "Nikos, o yüzden hiçbir yere gitmeden burada masada olman gerekiyor" yanıtını vermesi katıımcıları güldürmüş, umutları yeşerterek, beklentilere ışık tutmuştur. Zirvede yaşanan süreç Afrika gazetesi tarafından olumlu yaklaşımla resmedilerek haberleştirilmiştir. 


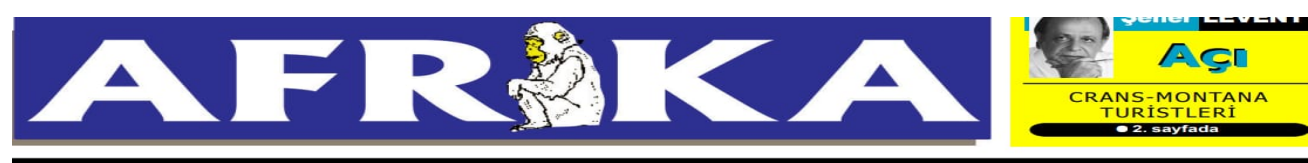

Türkiye Kıbrısıı Türkleri rehin tutmakta kararlı... İpler ha koptu, ha kopacak.
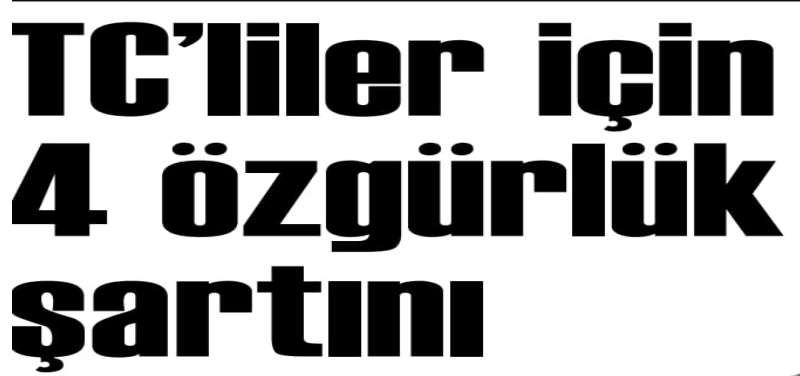

Konferansın birinci gününde, çözümün ertesi günü asker çekme önerisi yaptığı ileri sürülen TC Dıșișle 3akanı Mevlüt Cavuşoğlu ikinci gün ipleri koparacak noktaya geldi. "Kıbrıs sorunu güvenlik ve garantil ;orunu değildir" diyerek gerçek niyetini ortaya koydu. Ve TC'lilere 4 özgürlük şartını da cebinden çıkardı.

Şekil 4. Afrika'nın 30 Haziran Tarihli Manşet Haberi

30 Haziran 2017 tarihli “T.C.'liler için 4 özgürlük şartını masaya koydu” başlıklı haberde "Türkiye, Kıbrıslı Türkleri rehin tutmakta kararlı...jpler ha koptu, ha kopacak...", hemen altında iri puntolarla $A B$ yetkilisi Türkiye'nin 4 özgürlükle ilgili talebini desteklediğini, Anastasiadis'in toplantıyı teknik komite seviyesine düşürmek istediği görüşüne yer verip konuyla ilgili 'Türk tarafı, Rumlar açılım yapmadı ve konferansı çökertiyor diye yalan haberler yayılıyor. Şimdiden birbirine sorumluluk yükleme oyunları başladı', açıklamaları tırnaklı ifadelerle karşımıza çıkmaktadır. Bir önceki umut taşıyan söylemlerin aksine tarafların görüşleri ile sonuçlanan süreç Türk ve Rum yetkililere mal edilerek manşette yerini almıştır.

Tablo 4. Sürmanşet Haber Başlıkları

\begin{tabular}{|c|l|}
\hline Haberin Tarihi & \multicolumn{1}{c|}{ Haber Başlıkları } \\
\hline 20 Haziran 2017 & $\begin{array}{l}\text { Nikos Anastasiadis: Cenevre'ye herkesin güvenlik duygusunu tatmin } \\
\text { edebilecek bir sürü alternatif öneriyle gidiyoruz } \\
\text { Kıbrıs'ı satıyorlar }\end{array}$ \\
\hline 26 Haziran 2017 & Crans Montana seferleri başlıyor \\
\hline 27 Haziran 2017 & $\begin{array}{l}\text { Karar konferansı } \\
\text { Konferans Türkiye'yi uluslararası alanda teşhir etmek için iyi bir fırsat }\end{array}$ \\
\hline 28 Haziran 2017 & $\begin{array}{l}\text { Nikos Anastasiadis: Türkiye'nin tavrı değişmezse bu konferanstan sonuç } \\
\text { alınamaz }\end{array}$ \\
\hline
\end{tabular}

20 Haziran 2017 tarihli "Nikos Anastasiadis: Cenevre'ye herkesin güvenlik duygusunu tatmin edebilecek bir sürü alternatif öneriyle gidiyoruz" başlıkı haberin içeriğine bakıldığında her iki toplum tarafından çözümü başarmaya kararlı ve herkesin güvenlik duygusunu tatmin edecek bir öneri sunulduğu görülmektedir. Haber olumlu bir bakış açısıyla verilmiştir. 


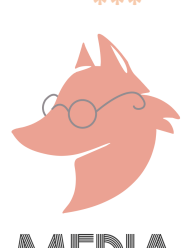

Cilt / Vol: $03-$ Sayı / No: $02 \quad$ e-ISSN: 2757-6035

MEDIAJ

20 Haziran 2017 tarihli Afrika gazetesi sol sütundan verilen ikinci sürmanşet haberinde Crans Montana zirvesindeki alternatif çözüm odaklı yaklaşımlara tepki gösteren, Türkiye'de ana muhalefet partisi CHP'nin Genel Başkanı Öztürk Yılmaz'ın "Türk askerinin kovulmasını, birleşik Kıbrıs'ın yaratılmasını, Türklerin azınlık hale getirilmesini" ifadelerini ve "Kıbrıs'ı satıyorlar" sözlerini tırnak içine almıştır. Haberde CHP'nin Kıbrıs sorunuyla ilgili çözüm istemediğini, olası bir çözüme köstek olmaya çalıştığını vurgulamıştır. Bu bağlamda haber içeriğinden çözüm süreciyle ilgili Türkiye'ye yönelik olumsuz bir bakış açısının varlığı anlaşılmaktadır.

26 Haziran 2017 tarihli orta alt sürmanşet "Crans Montana seferleri başlıyor" haber başlığının tırnak içine alınmadığı görülmüştür. Çözüme ilişkin heyette, Kuzey Kıbrıs yetkilileri; Barış Burcu, Erhan Erçin, Sertaç Güven, Meltem Onurkan Samani, Sülen Karabacak, Ipek Genç, Halil Sadrazam, Ömer Gökçekuş, Layık Mesutoğlu’nun yer aldığı, ifadelerin devamında hükümeti Denktaş ve Ertuğruloğlu'nun temsil edeceği bilgisiyle, zirvenin kaç gün süreceğine dair açıklama yapılmaktadır. Haber içeriğinin bilgilendirme amaçlı ve objektif olduğu görünmektedir.

27 Haziran 2017 tarihli "Karar konferansı" başlıklı haberde elli yıllık geçmişe sahip Kıbrıs sorununun artık son aşamaya geldiğini belirten K.K.T.C Cumhurbaşkanı Akıncı'nın görüşlerine yer verilerek, Crans Montana'da paralel iki masanın kurulacağı...birinde Kıbrıs, Türk, Rum taraftarları ve üç garantör ülkenin bulunacağı gözlemci olarak $A B^{\prime}$ nin bulanacağı açıklamasına yer verilerek, müzakerelerin, konferanstan öte bir karar konferansı olacağı ifadelerine yer verilmiştir. Yine aynı tarihli gazetede bir başka haberde tek cümle ile verilen Akel'in görüşünde: “Konferans Türkiye'yi uluslararası alanda teşhir etmek için iyi bir fırsat..." ifadelerine yer verilmiştir. Bu ifade Türkiye'yi suçlamaya yönelik, yanlı bir bakış açısını içinde barındırmaktadır. Afrika bunu sürmanşetten vermeyi tercih ederek vererek bu bakış açısı ve tutumun yanında yer almıştır.

28 Haziran 2017 tarihli gazete haberlerinde ise Nikos Anastasiadis'in görüşlerine yer verilerek, "Türkiye'nin tavrı değişmezse bu konferanstan sonuç alınamaz..." başığı atılmıştır. Bu haber başlı̆ına ait haber içeriği iç sayfalardadır. Ancak sadece başlığın bu şekilde yazılmış olması bile karşı tarafın bakış açısıyla sorumluluğu Türkiye'ye yüklemekte ve Türkiye'yi uzlaşmaz göstererek alenen zan altında bırakmaktadır. Afrika'nın sürmanşetlerinde Rum tarafının özellikle Türkiye aleyhine söylediği ifadeleri cımbızla çekerek habere taşıması, aynı suçlayııı tavrın kendisinde de var olduğunun bir göstergesi olarak değerlendirilebilir.

\section{Kıbrıs'ta Manşet ve Sürmanşetten Verilen Haberlerin Analizi}

Kıbrıs'ın manşetten verdiği haberlere ilişkin başlıklar aşağıdaki tabloda görüldüğü gibidir.

Tablo 5. Kıbrıs Manşet Haber Başlıkları

\begin{tabular}{|c|c|}
\hline Haberin Tarihi & Haber Başlıkları \\
\hline 29 Haziran 2017 & Başlangıç fena değil \\
\hline
\end{tabular}




\section{MEDIAJ}

Tablo 5'te görüldüğü gibi 20- 30 Haziran 2017 tarih aralığında bir tane manşet haber görülmektedir, diğer günler konuyla manşetten haber verilmemiştir.

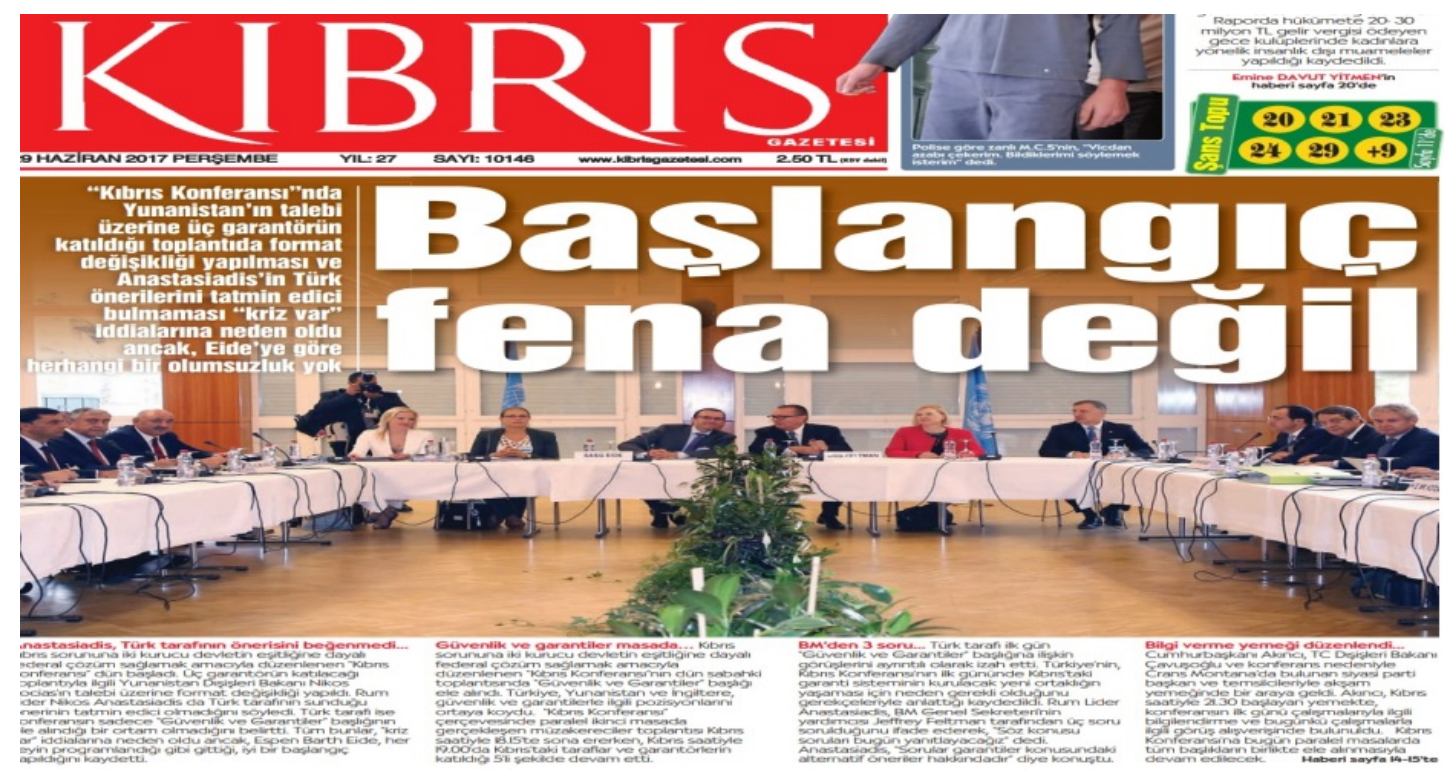

Şekil 5. Kıbrıs'ın 29 Haziran Tarihli Manşet Haberi

"Başlangıç fena değil" başlığıyla verilen haberde "iki kurucu devletin eşitliğine dayalı federal çözüm sağlamak amaçlı düzenlenen toplantıda "Güvenlik ve Garantiler" başlığı ele alındı. Türkiye, Yunanistan, İngiltere güvenlik ve garantilerle ilgili pozisyonunu ortaya koydu". Ayrıca "Kıbrıs Konferansı" çerçevesinde paralel ikinci masada gerçekleşen müzakereciler toplantısının 5'li şekilde devam ettiği ifade edilmiştir. Haberde Rum Lideri Nikos Anastasiadis, BM Genel Sekreteri Yardımcısı Jeffrey Feltman, Cumhurbaşkanı Mustafa Akıncı, T.C Dışişleri Bakanı Mevlüt Çavuşoğlu siyasi başkan ve temsilcilere de yer verilmiştir. Haber içeriğine bakıldığında objektif bir şekilde yorum yapılmaksızın konuşulan konulara yer verildiği görülmüştür. Görüşmenin tüm taraflarının haber içeriğinde yer alması, konunun kapsamıyla ilgili tam bir bakış açısı sağlamaya yöneliktir, şeklinde değerlendirilebilir. 
MEDIAJ

Tablo 6. Kıbrıs Sürmanşet Haber Başlıkları

\begin{tabular}{|c|l|}
\hline Haberin Tarihi & \multicolumn{1}{c|}{ Haber Başlıkları } \\
\hline 20 Haziran 2017 & $\begin{array}{l}\text { Yıldırım ve Çipras'tan çözüme güçlü destek } \\
\text { Ertuğruloğlu, Çavuşoğlu ile görüştü }\end{array}$ \\
\hline 21. Haziran 2017 & $\begin{array}{l}\text { Kıbrıs müzakere süreci ele alındı. } \\
\text { Türkeş bugün K.K.T.C' ye geliyor. } \\
\text { Eide bugün belgeyi taraflara sunuyor. }\end{array}$ \\
\hline 22. Haziran 2017 & $\begin{array}{l}\text { Türkeş: Çözümü istemeyenin kim olduğu görülmeli. } \\
\text { "Kıbrıs Konferansı için büyük hazırlık” }\end{array}$ \\
\hline 23 Haziran 2017 & Türkeş 5 saatini partililere ayırdı. \\
\hline 25 Haziran 2017 & Türkiye de Cenevre'den sonuç bekliyor. \\
\hline 26 Haziran 2017 & 15 günlük maraton başlıyor; hadi hayırlısı. \\
\hline 28 Haziran 2017 & $\begin{array}{l}\text { Konferansta ortak belge sunmayacağız. } \\
\text { Gözler kulaklar Crans Montana'da. } \\
\text { Kıbrıs'ın yeniden birleşmesini sağlayalım. }\end{array}$ \\
\hline 30 Haziran 2017 & $\begin{array}{l}\text { Rum tarafı 16 sayfa, Türk tarafı 1,5 sayfa yazdı. } \\
\text { Sıfır asker, sıfır garanti hayal. }\end{array}$ \\
\hline
\end{tabular}

Illgili süreçte Kıbrıs'ta Crans Montana Görüşmeleriyle ilgili sürmanşetten verilen haber sayısı Tablo 6'da da görüldüğü gibi 15'tir. 24 ve 27 Haziran günleri haricinde hergün sürmanşetten haber girilmiştir.

Kıbrıs'ın 20 Haziran 2017 tarihli sürmanşet haberlerinden “Yıldırım ve Çipras'tan çözüme güçlü destek" başılıkı haberin ayrıntılarında; Atina'da görüşen Türkiye Başbakanı Binali Yıldııı ile Yunanistan Başbakanı Aleksis Çipras, Kıbrıs Sorununa çözüm bulma sürecindeki iş birliğini devam ettirme konusunda mutabık kaldıklarını açıkladı. Yıldırım, "Olumlu düşünceler içerisindeyiz" dedi. Çipras, "Sorunun çözülmesi için çalışıyoruz" ifadelerine yer verilmiştir. Öncelikle gazetenin verdiği haberin başlığına bakıldığında, başlıkta kullanılan sözcüklerin tamamının olumlu olduğu görülmektedir. Haberin devamına bakıldığında ise bu tutumun devam ettiği, taraflarca çözüme odaklanılan, yapıcı bir yaklaşım sergilendiğine yönelik ifadelere yer verilmiştir. Haber objettif, tüm aktörlere eşit yer vermiş bir haberdir.

20 Haziran 2017 tarihinde gazetenin sürmanşetten verdiği ikinci haberde, "Ertuğruloğlu, Çavuşoğlu ile görüştü" başlığı atılmıştır. Haberde, Ertuğruloğlu’nun "Anavatanımızın, tek taraflı müdahale hakkını içermeyen garanti sistemi, garanti sistemi olmaz", Çavuşoğlu'nun "Kıbrıs Konferansını nihai konferans olarak görüyoruz" ifadelerine yer verilmiştir. Anavatan'ın desteğini, KKTC ve Anavatanın bölünmez bütünlüğünü vurgulayan haberde çözüm odaklı sonuç çıkacağına yönelik olumlu bir bakış açısı görülmektedir

21 Haziran 2017 tarihinde gazetede, “Kıbrıs müzakere süreci ele alındı”, “Türkeş bugün K.K.T.C' 


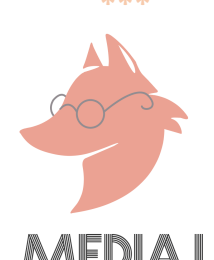

Cilt / Vol: $03-$ Sayı / No: $02 \quad$ e-ISSN: 2757-6035

MEDIAJ

ye geliyor" ve "Eide bugün belgeyi taraflara sunuyor" olmak üzere çözüm süreci Crans Montana görüşmeleriyle ilgili üç haber başlığı görülmektedir. "Kıbrıs müzakere süreci ele alındı", sürmanşet haberinin devamı iç sayfalarda verilmekle birlikte Türkiye Cumhuriyeti Cumhurbaşkanı ile Kuzey Kıbrıs Dışişleri Bakanı Ertuğruloğlu buluşmasına ait fotoğrafa haberde yer verilmiştir. Müzakerelerle ilgili görüş ve bilgilerin ele alındığı haberin objektif olarak yayınlandığı değerlendirebilir. Yine aynı tarihli gazetede verilen sol alt sürmanşetten verilen "Türkeş bugün K.K.T.C'ye geliyor" haberinde Alpaslan Türkeş'in fotoğrafına yer verilmiş, ancak başka bir detay verilmemiş, haber iç sayfalarda devam etmiştir. "Eide bugün belgeyi taraflara sunuyor" sürmanşeti de aynı tarihlerde fotoğrafsız, sadece başlık olarak verilmiştir. İlgili tarihlerde olumsuz bir habere ve ifadeye rastlanılmamıştır.

22 Haziran 2017 tarihinde sürmanşetten iki haber verilmiştir. Bunlardan ilkinde "Türkeş: Çözümü istemeyenin kim olduğu görülmeli" başlığı kullanılmıştır. Bu ifade ile gazete Türk tarafının çözüm kararlılığına dikkat çekip vurgulayarak bu durumu ön plana çıkartmıştır. Öte yandan ısrarla artık bir çözüm olmasını bekleyen ülke portresi çizilmiştir. Bir diğer sürmanşet haberinde "Kıbrıs Konferansı için büyük hazırlık" haber başlığı göze çarpmaktadır. BM Genel Sekreteri Kıbrıs özel danışmanı Eide, Kıbrıs Konferansına rehberlik etmesi amacı ile hazırlanan belgenin taraftarlara sunumu için, Cumhurbaşkanı Akıncı ve beraberindeki heyetin Türkiye'ye gittiğini, ABD Başkan yardımcısı Mike Pence'in, Akıncı ile yaptığı telefon görüşmesinde ABD'nin vereceği destekten söz edilmiştir. Haberde taraflara eşit mesafede durulmuş ve yapıcı bir tutum sergilenmiştir.

23 Haziran 2017 tarihli gazetedeki sürmanşet haber, "Türkeş, 5 saatini partililere ayırdı" başlığını taşımaktadır. T.C Lefkoşa Büyükelçiliğinde yapılan toplantıda Kuzey Kıbrıs'ta bulunan tüm partili yetkililerle bir araya gelerek, müzakere öncesinde Kıbrıs'taki genel havayı, farklı siyasi partilerin konuya nasıl baktığını öğrenmek için görüşmeler yaptığı bu kabulde partililerden çözüm odaklı, adil, eşitlikçi bir tutum sergilemeleri yönünde iş birliği beklediği ifadelerine yer verilmiştir.

25 Haziran 2017 tarihli gazetede sürmanşet haber olarak, "Türkiye de Cenevreden sonuç bekliyor" başlığına yer verilmiştir. Adadaki Türk varlığının geleceğinin Türkiye açısından da önemli olduğu, dolayısıyla ilgili süreçte Türkiye'nin taraflardan biri olduğuna vurgu yapılmıştır. Cenevre'den bir sonuç çıkmasının Kuzey Kıbrıs kadar Türkiye için de beklenilen bir durum olması her iki ülkenin birlikte hareket ettiğini ve ortak hareket edildiğini ifade etmektedir. Gazetenin yaptığı bu haber ikili fikir birliğine işaret etmektedir.

26 Haziran 2017 tarihli gazetede yer alan, "15 günlük maraton başlıyor; hadi hayırlısı" sürmanşetli haber başlığı ile zirve toplantısının desteklendiği ve çözüme yönelik umut sahibi olunduğu yönünde bir ifade şeklinde değerlendirilebilir. Yapılan haber sürece yönelik ılımlı bir bakış açısını yansıtmaktadır.

28 Haziran 2017 tarihli gazetede, "Konferansta ortak belge sunmayacağız" başlıklı haber 


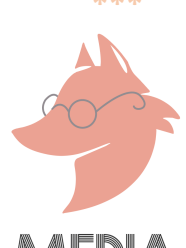

sürmanşetten verilmiştir. BM Genel Sekreteri Kıbrıs Özel Danışmanı Eide'nin "güvenlik ve garantiler" başlığında rehber olacak ortak belgenin taraftarlarca kabul edilmemiş olması nedeniyle belgenin sunulmayacağını ifade etmesinin haberi yer almıştır. Haber objektif olarak, herhangi bir yorum katılmadan nesnel bir şekilde aktarılmıştır. Yine aynı gün, "Gözler kulaklar Crans Montana'da" başlığıyla verilen haberde toplantının çözüm süreci için ne denli önemli olduğu vurgulanmıştır. Haberde çözüm sürecinin geleceğiyle ilgili beklenti, merak ve endişe unsurları katılarak dile getirilmiştir. Yine olumlu ve olumsuz bir dil kullanılmamış, habere yanlı bir bakış açııı yansıtılmamıştır. "Kıbrıs'ın yeniden birleşmesini sağlayalım”, sürmanşet haberinde ise çözüm sürecinde rol alan tarafların sürece ilişkin olumlu görüşlerine yer verildiği görülmüştür. Haberin dili ve yönü pozitif ve yapıcıdır.

30 Haziran 2017 tarihli gazetede yer alan "Rum tarafı 16 sayfa, Türk tarafı 1,5 sayfa yazdı" ve "Sıfır asker, sıfır garanti hayal" başlıklı sürmanşet haberleri ile sürecin sekteye uğradığı ilk bakışta anlaşılabilmektedir. İlk haberde iki tarafın eşitsiz durumu ele alınmış, Rum tarafına yönelik üstü kapalı bir siteme yer verilmiştir. Yeni Düzen'de manşet ve sürmanşetten verilen haberlerin analizi

Yeni Düzen'in manşetten verdiği haberlere ilişkin başlıklar aşağıdaki tabloda görüldüğü gibidir.

Tablo 7. Yeni Düzen Manşet Haber Başlıkları

\begin{tabular}{|c|c|}
\hline Haberin Tarihi & Haber Başlıkları \\
\hline 29 Haziran 2017 & TÜRKIYE'DEN ASKER AÇILIMI...! \\
\hline 30 Haziran 2017 & ZIRVEDE KIRITIK GÜN \\
\hline
\end{tabular}

Tablo7'de görüldüğü gibi 20-30 Haziran 2017 tarih aralığında iki tane manşet haber görülmektedir, diğer günler konuyla ilgili manşetten haber verilmemiştir.

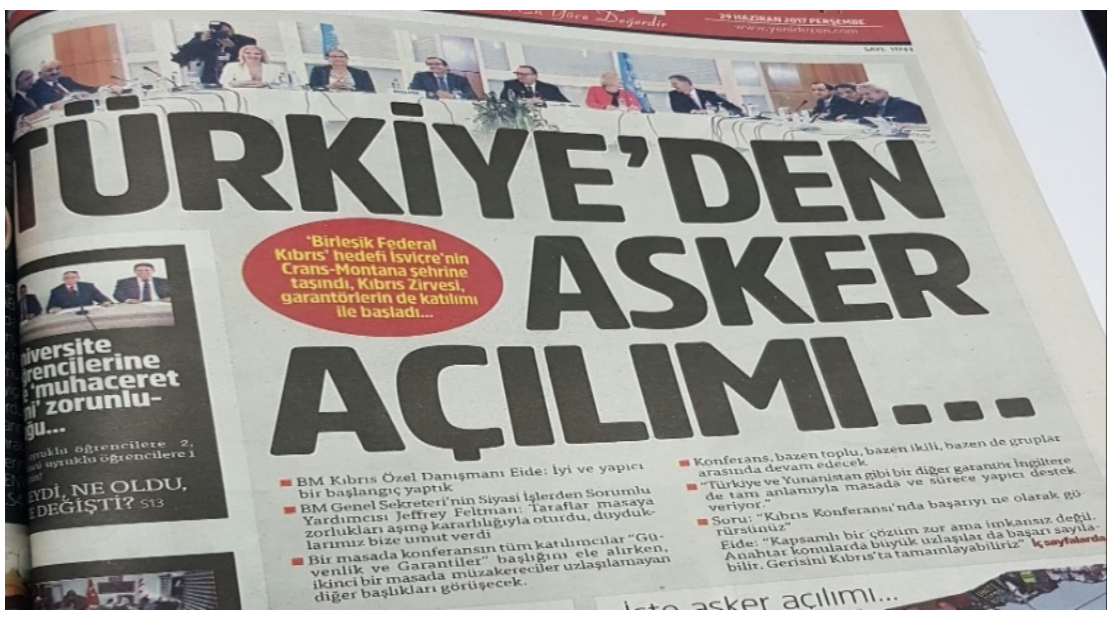

Şekil 6. Yeni Düzen'in 29 Haziran Tarihli Manşet Haberi 


\section{MEDIAJ}

29 Haziran 2017 tarihine kadar Crans Montana görüşmeleriyle ilgili Yeni Düzen'de manşet haber verilmemiştir. "TÜRKIYE'DEN ASKER AÇILIMI" başlığıyla verilen sürece ilişkin manşet haberinin iri puntolarla oluşturulduğu görülmüştür. Haberin içeriğinde, Türkiye'nin çözümü takip eden ilk günde önemli miktarda askerin çekilmesi ve geriye kalan askerlerin çekilmesinin Federal Kıbrıs'ın işleyişine bağlı olarak takvimlendirilmesi önerisini gündeme almıştır. Gazetenin verdiği haber içeriğiyle Federal bir başkanlık sistemini destekleyen bir tutum sergilediği görülmüştür.

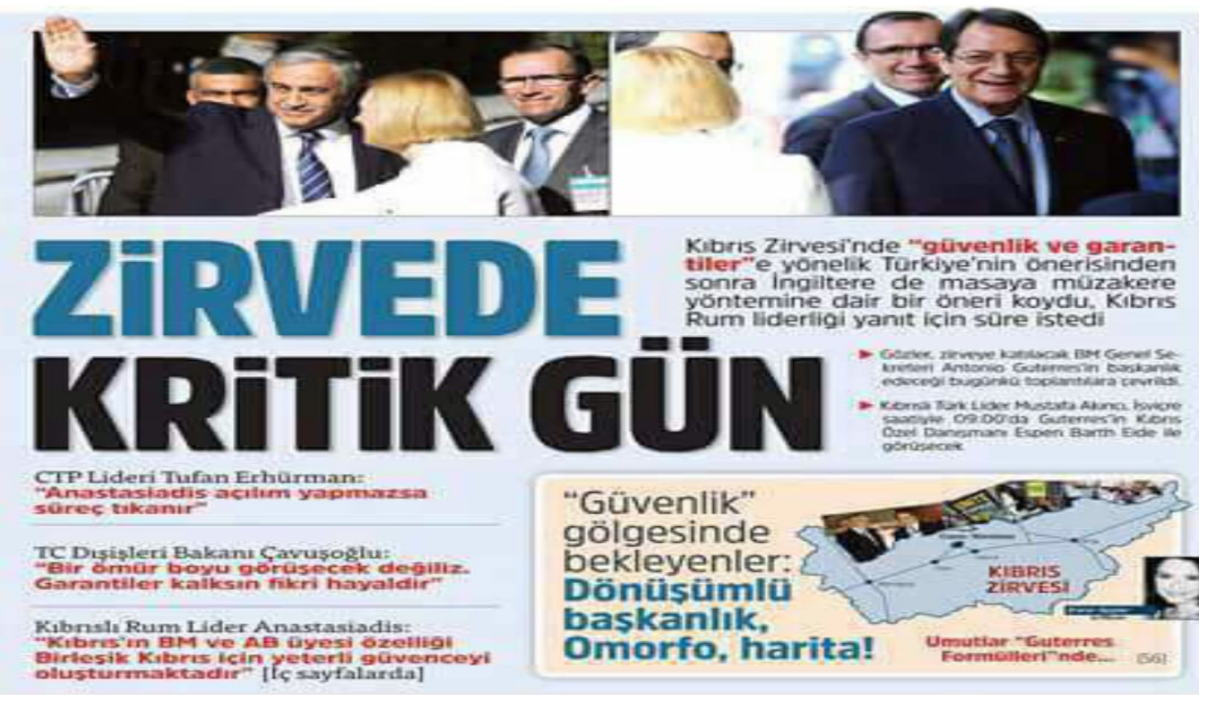

Şekil 7. Yeni Düzen'in 30 Haziran Tarihli Manşet Haberi

30 Haziran 2107 tarihli "ZiRVEDE KIRiTiK GÜN" manşet haberi yine iri puntolarla yazılmış olduğu görülmüştür. "Kıbrıs Zirvesinde 'güvenlik ve garantiler'e yönelik Türkiye'nin önerisinden sonra Ingiltere de masaya müzakere yöntemine dair bir öneri koydu. Kıbrıs Rum Lideri yanıt için süre istedi" ifadelerine yer verilmiştir. Haberde ulusal çıkarlarını ön plana çıkaran çözüm sürecine ilişkin tarafların görüşlerine yer verilirken gazetenin süreci kendi görüşlerine yönelik içselleştirildiği kanaatine varılmıştır.

Tablo 8. Afrika Sürmanşet Haber Başlıkları

\begin{tabular}{|c|c|}
\hline Haberin Tarihi & Haber Başlıkları \\
\hline 21 Haziran 2017 & Eide müzakerecilere taslak metnini sunacak \\
\hline 23 Haziran 2017 & $\begin{array}{l}\text { Akıncı, "Artık bir sonuç alınmalı" } \\
\text { Erhürman, "Kararlılık ve cesaretle sonuç odaklı bir yaklaşım } \\
\text { gerek..." }\end{array}$ \\
\hline 27 Haziran 2017 & Akıncı, Bu bir müzakere konferansı değil, Karar Konferansıdır \\
\hline 28 Haziran 2017 & $\begin{array}{l}\text { "BELGESIZ BAŞLIYOR, BM içiN KARAR ZAMANI”. } \\
\text { BM SEKRETERI GUTTERES: BiRLEŞME FIRSATINI DEĞERLENDIRIN! } \\
\text { "Kıbrıs Konferansı çözüm için son değil, en büyük şans" }\end{array}$ \\
\hline 29 Haziran 2017 & $\begin{array}{l}\text { Yunanistan'dan } 2 \text { öneri! } \\
\text { İşte asker açılımı }\end{array}$ \\
\hline
\end{tabular}




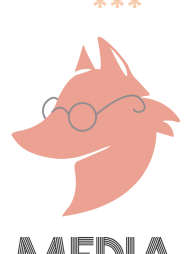

Cilt / Vol: 03 - Sayı / No: $02 \quad$ I $\quad$ e-ISSN: 2757-6035

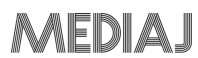

20-30 Haziran 2017 tarihli Yeni Düzen gazetesinin sürmanşet olarak verdiği haberlere ilişkin başlıklar Tablo8'de gibidir.

21 Haziran 2017 tarihli gazetede verilen, "Eide müzakerecilere taslak metnini sunacak" başlıklı haberde Yunanistan, İngiltere, Türkiye yanında gözlemci olarak da AB'nin katılımıyla başlayacak olan müzakere öncesi vereceği taslak metni ile ilgili davranışsal süreçleri ele almış ve haberde Eide'nin fotoğrafını vermiştir.

23 Haziran 2017 tarihli Akıncı'nın "Artık bir sonuç alınmalı" ifadesine yer veren sürmanşetli haberde Kuzey Kıbrıs Cumhurbaşkanı Akıncı'nın sonuç odaklı ve kalııı bir barışın sağlanması yönündeki beklentisi vurgulanmıştır. İç sayfalarda yer alan haber Akıncı'nın fotoğrafı ile Kıbrıs Türk toplumunun siyasi ve ideolojik mücadelesinin desteklenmesine yönelik ara manşetlerle olumlu tutum sergilenmiş, vurgulanmak istenilen noktalar ön plana çıkartılmıştır. Bir diğer sürmanşetten verilen haberde CTP Lideri Erhürman'ın, "Kararlılık ve cesaretle sonuç odaklı bir yaklaşım gerek..." ifadesine yer veren gazete, olumlu bir tutum sergileyerek beklenti ve çözüm odaklı bir sürecin önemine vurgu yapmıştır. Bu iki sürmanşet haber ile Akıncı ve siyasi parti başkanlarının sonuç odaklı bir beklenti içinde, kalıcı barışın sağlanması yönündeki kararlılığı vurgulanmıştır. İç sayfalarda haberin devamında Akıncı'nın fotoğrafı ile Kıbrıs Türk toplumunun siyasi ve ideolojik mücadelesinin desteklenmesine yönelik ara manşetlerle vurgulanmak istenilen noktalar ön plana çıkartılmıştır.

27 Haziran tarihli gazetede yer alan haberde Akıncı'nın, “Bu bir müzakere konferansı değil, Karar Konferansıdır" sözlerine yer verilmiştir. Cümlenin ikinci tarafındaki yan cümlenin büyük harflerle yazılmış olması Akıncı'nın söylediklerine önem atfetmesinin yanısıra okuyucudaki etkiyi arttırma amacı taşımaktadır. Sürecin ve görüşmenin önemine işaret eden bu başlık beklentinin yüksek ve hayati olduğuna işaret etmektedir.

28 Haziran tarihli gazetede ilk sayfada yer alan, "BELGESIZ BAŞLIYOR, BM IÇiN KARAR ZAMANI" sürmanşeti ile spottan verilen haberde BM Genel Sekreteri Antonio Gutterres'in Crans Montana Zirve Konferansında alınacak kararlarla ilgili belirleyici olması yönünde olumlu görüşlerine yer verilmiştir

"BM SEKRETERI GUTTERES: BİRLEŞME FIRSATINI DEĞERLENDIRIN!” şeklinde verilen ikinci sürmanşette, BM Genel Sekreteri Gutteres tarafından, taraflara tavsiye nitelikli mesaj verilmiş, gazete Gutteres'in tek fotoğrafı ile haberin detaylarını iç sayfalarda vermiştir. Haberin devamında, BM'nin Doğu Akdeniz bölgesi için değerlendirme çağrısı yaptığını, bu çabalara destek verdiğini, her iki tarafın barıştan yana fırsatı değerlendirmesi gerektiği ifadelerine yer vermiştir.

“Kıbrıs Konferansı çözüm için son değil, en büyük şans”, başlıklı haberde konuyla ilgili olarak, ilgili 


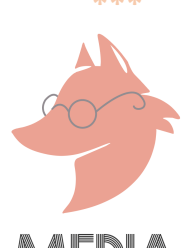

tarafın görüşü tırnak içinde verilerek ifadeye dikkat çekilmek istenmiştir. BM Genel Sekreteri Kıbrıs Özel Danışmanı Espen Barth Eide'nin konferans ve çözüm süreci ile ilgili fırsat niteliğindeki bu görüşü bir kare fotoğraf ile olumlu bir şekilde sayfada yer almıştır. Bu başlıklarla Yeni Düzen gazetesinin barış yanlısı olduğu olumlu tutum sergilediği kanaatine varılmıştır.

29 Haziran 2017 tarihli gazete yer alan "Yunanistan'dan 2 öneri! İşte asker açılımı!" başlıklı haberlerde, Rum Lideri Dışişleri Bakanı Nikos Kotzias tarafından garanti anlaşmasının ve müdahale hakkının ortadan kaldırılması yönündeki iki öneri haberi yer aldığı ve ilgili tarafın görüşüne yer verirken cümle sonunda ünlem işaretinin konulması Kuzey Kıbrıs'ın aleyhine, zorlayıcı bir duruma dikkat çekmiştir.

Diğer sürmanşet, "İşte asker açılımı" başlıklı haberde T.C yetkililerinden çözüme dayalı öneriyi ele alarak, önemli miktarda askerin çekilmesi ve geriye kalan askerlerin çekilmesinin Federal Kıbrıs'ın işleyişine bağlı olarak takvimlendirileceği, ilerlemenin buna bağı olacağı ifadesine yer verilmiştir. Birleşme için Türk askerinin çekilmesini şart koşarak, karşı tarafın Ada'da Türk askerini ve varlığını istemediği ve bunu pazarlık konusu yaptığı vurgulanmıştır. Yeni Düzen bunu gündemde tutarak ilgili sürecin Kıbrıs Türkünün aleyhine ilerlediğine dikkat çekmek istemiştir.

\section{SONUÇ}

Demokratik toplumlarda basının en temel ilkesi haber vermek, yönetilenler ve yönetenler arasında köprü görevi görmektedir. Kişilerin bilmek, öğrenmek haklarının gerçekleşmesine katkıda bulunma işlevi nedeni ile de haber, hayatın vazgeçilmez unsurudur. Haberin, haber niteliğini oluşturabilmesi için ise bazı özelliklere sahip olması gerekmektedir. Öncelikle haberin olay/olgu/fikir ve sorunun okur/dinler ve izler kitlelere bazı bilgileri taşıması gerekmektedir. Dolayısı ile gündemi takip ederek, hızlıca tarafsız, objektif bir şekilde ilginç gelen olguları nesnel olarak yayınlaması gerekmektedir.

Kıbrıs sorunu Ada'da yaşayan Kıbrıslı Türklerin ve Kıbrıslı Rumların yıllardır birbiriyle çatışan sosyo- politik, ekonomik, stratejik çıkarları nedeniyle günümüze kadar gelmiştir. Aynı zamanda adanın jeopolitik ve stratejik öneminden dolayı bölgesel ve küresel güçlerin çıkarları yönünde Kıbrıs Sorunu uzun yıllar devam etmiştir. Yıllarca Kıbrıs Türk halkı Enosis'e karşı ve devlet olma yönünde büyük mücadele vermiştir. Yarım asırdır devam eden sorunlara çözüm bulma politikasıyla, Türkiye, İngiltere ve Yunanistan'ın garantörlüğünde iki kurucu devletin siyasi eşitliğine dayalı kapsamlı çözüm bulma umutları çerçevesinde müzakerelerin sonuncusu İsviçre'nin Crans Montana şehrinde yapılmıştır. BM gözetimi içinde gerçekleşen Crans Montana Kıbrıs sorununa çözüm arayışları bir noktada satranç oyununa dönmüştür. Annan planına örnek olacak yaklaşımla "Güvenlik ve Garantiler ile Türk askerinin Adadan çekilmesine" yönelik şartına karşın T.C tarafının elinden geleni yapması yine sonuçsuz kalmıştır. Bu süreçte medyaya büyük görevler düşmüş, 2017 yılında gerçekleştirilen Crans Montana Kıbrıs Sorunu çözüm süreci Kuzey 


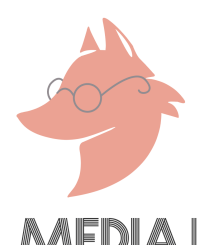

Kıbrıs'ta medyayı farklı görüşlere ayırmış, taraftarları manipüle edici ve propaganda amaçlı haberlerin oluşturulduğu görülmüştür. Zirve sonrası siyasi partilerin kitle iletişim araçları tarafından yayımlanan haberleri propaganda aracı olarak kullanılmaya devam etmiş ve iktidar partisinin Türkiye, $A B$ ve Kıbrıs sorununda mevcut statükonun korunması siyasetini günümüze kadar getirmiştir. Sorunlar devlet politikası olarak değil hükümet politikası olarak algılanmış ve seçim malzemesi olarak kullanılmıştır. Medyanın kamuoyunun duygusallığından istifade ederek gündemi hükümet politikaları ile orantılı olarak kullanması ve yayın politikası belirlemesi göze çarpmıştır.

Afrika, savunduğu siyasi görüş çerçevesinde manşetlerde tarafların adları ve ifadelerine yer vermiş, haberlerde kim konuşuyor ve nasıl gibi sorularına cevaben mecaz anlam içeren haber başıklarını sayfalarına taşımıştır. Federatif bir yapılanma ekseninde, barış ve birleşmeden yana tutum sergileyen gazete, kalıcı barışın sağlanamamasından Türkiye Cumhuriyeti ve Rum yetkililerini sorumlu tutmuş, eleştirel, sitemkâr ve bazen de alaycı bir yaklaşımla haberi şekillendirmiştir. Kıbrıs ise Crans Montana'da gerçekleşen zirveye ait verdiği haber başıklarında, tarafların görüşlerine ağırlık vermiştir. Kıbrıs Türkünün çıkarları ve bağımsız olarak varlığını sürdürmesi, ulusal birliğin sağlanması yönünde haber başıılarını oluşturmuştur. Aynı zamanda tarafların demeçlerine eşit yer vermiş, olumlu dil kullanmış ve yapıcı bir tutum gözetmiştir. Yeni Düzen zirve sürecinde hükümet yanlısı bir tutum sergileyerek, bu yönde haber içerikleri oluşturmuştur. Haber başlıklarında ulusal çıkarları ön plana çıkarmış, Kıbrıs Türk toplumunun siyasi ve ideolojik mücadelesinin desteklenmesine yönelik noktaları ön plana çıkartmış, olumlu bir habercilik sergilemiştir.

Çalışmanın sonucunda adı geçen gazetelerin, ideolojileri ekseninde habercilik pratiklerini gerçekleştirdikleri, ancak Afrika'nın temel habercilik ilkelerinin dışına çıkan ifadelere sıklıkla yer verdiği sonucuna ulaşılmıştır.

\section{KAYNAKÇA}

Altay, H. Ş. (1969). Kıbrıs Türk Basın Kaynakları. Lefkoşa.

Althusser, L. (2014). Ideoloji ve Devletin Ideolojik Aygıtları. (Çev. Alp Tümertekin). İstanbul: İthaki Yayınları

Asit, G. (2019). Kuzey Kıbrıs Türk Cumhuriyeti Medyasında Etik Sorunsalı: Kürtaj Davası Haberleri Örneği. Gümüşhane Üniversitesi Iletişim Fakültesi Elektronik Dergisi, 7(1), 321-344.

Aslan, K. (2002). Haberin Yol Haritası, İstanbul: Anahtar Kitaplar Yayınevi.

Arık, U. (2011). Kıbrıs Krizi. LAÜ Sosyal Bilimler Dergisi, 2 (1), 3-21

Atabek, N. (1994). Gazetecilikte Tarafsızlık. Marmara iletişim Dergisi. Sayı 7, Temmuz. 
Atun, A. (2018). Crans Montana ve Kıbrıs Gerçeği Erişim Tarihi: 07 Mayıs 2018 http://ankaenstitusu.com/crans-montana-ve-kibris-gercegi/

Azgın, B. (1998). The Turkish Cypriot Mass Media. Cyprus: Handbook on South Eastern Europe, der., K.D. Grothusen, W. Steffani ve P. Zervakis. Germany: Vandenhoeck \& Ruprecht in Gottingen.

Aziz, A. (2010). Iletişime Giriş (Genişletilmiş 3. Baskı). İstanbul: Hiperlink Yayınları.

Altan Bayraktar, Ü. (2015). Kıbrıs Sorunu Çözüm Sürecinde Annan Planı ve Referandumu'nun KKTC ve Kıbrıs Rum Basınındaki Stratejik Sunumunun Analizi. Istanbul Arel Üniversitesi Illetişim Çalışmaları Dergisi, 4 (8), 13-50.

Bozkurt, E. ve Demirel, H., (2004). BM ve AB Kapsamında Kıbrıs Sorunu, 1. Baskı, Ankara: Nobel Yayınevi.

Bulut, S. ve Yaylagül, L. (2004). Türkiye'deki Yazılı Basında Yargıtay ve Mafya iliş̧kisine Yönelik Haberler, Ankara: Gazi Üniversitesi Iletişim Fakültesi Iletişim Dergisi, Sayı:19.

Burton, G. (1995). Görünenden Fazlası, Medya Analizlerine Giriş. (Çev: Nefin Dinç) İstanbul: Alan Yayınları.

Ceylanlı, B. ve Kanlı, i. (2020). KKTC'de Yaşanan Kadın Cinayetlerinin Basındaki Yansımaları: Ana Akım ve Alternatif Gazete Karşılaştırması. Türkiye Iletişsim Araştırmaları Dergisi, (35), 238-261.

Devran, Y. (2010). Haber, Söylem, Ideoloji, İstanbul: Başlık Yayın Grubu.

Fowler, R. (1991). Language in the News: Discourse and Ideology in the Press, London: Routledge.

Gee, P. G. (2008). Social Linguistics and Literacies: Ideology in Discourses. London: Routledge.

Gramsci, A. (2006). History of the subaltern classes;(ii) The concept of "ideology" ;(iii) Cultural themes: Ideological material. (2nd. Edition) Media and Cultural Studies: Keyworks, 1317.

Güz, N. (2008). Kamuoyu Araştırmalarının Medyada Yayınlanmasının Etik Ilkeleri, Medya ve Siyaset, Zülfikar Damlapınar (edt), Konya, Eğitim Kitabevi, s:11-37.

Hall, S. (1977). The Hinterland Of Science: Ideology And 'The Sociology Of Knowledge'. On ideology, 10. London: Routledge

Hall, S. (1980). The Rediscovery of Ideology: Return of the Repressed in Media Studies. Culture, Media, Language içinde. Der. S. Hall, D. Lowe vd. London: Routledge. 
Işık M (2008) Türkiye'deki İletişim Sisteminin Medya Siyaset iliş̧kilerine Yansımaları, Zülfikar Damlapınar (Ed), Medya ve Siyaset, Konya: Eğitim Kitabevi. s. 147-163.

İrvan, S. (2006). Kıbrıslı Türk Gazetecilerin Mesleki ve Etik Değerleri, Küresel Illetişim Dergisi, 1, 1-14.

Kalelioğlu, O. (2008). Türk-Yunan iliş̧kileri ve Megali İdea, Ankara Üniversitesi Türk Inkılâp Tarihi Enstitüsü Atatürk Yolu Dergisi, s.105-123.

Karaduman, S. S. (2009). Televizyon Haberlerinde Egemen İdeoloji ve Farklı Kimliklerin Temsili, Doktora Tezi, Ege Üniversitesi Sosyal Bilimler Enstitüsü, İzmir.

Marx, K. ve Engels, F. (1999). Alman Ideolojisi, (Çev: S. Belli), Ankara: Sol Yayınları, 4. Baskı.

Orhon, N. (2004). Değişim Değeri Açısından Televizyon Haberi Teknolojik ve Ideolojik Boyutuyla Metalaşan Televizyon Haberleri, Eskişehir: Anadolu Üniversitesi Yayınları.

Öksüz, O. (2007). Kamuoyu Oluşum Sürecinde Basın Siyaset Etkileşiminin Etik Açısından Değerlendirilmesi: Kıbrıs Müzakerelerinin Hürriyet Gazetesinde Sunumu. Selçuk iletişim Dergisi $5: 1$.

Polat, N. (2011). Kuzey Kıbrıs Türk Cumhuriyeti Yazılı Basınında Kişisel illanlar ve Ölüm Ilanları. İstanbul Üniversitesi Iletişim Fakültesi Dergisi, (40), 87-100.

Sandıklı, A. ve Erdem, K. (2017). Teoriler Işığında Türk-Yunan Iliş̧kilerinde Ege Sorunu, Erişim Tarihi: 04 Mart 2020 www.bilgesam.org/Images/Dokumanlar

Selçuk, A. ve Şeker, M. (2012). Danıştay Saldırısı Haberlerinde Söylem ve Ideoloji, Ankara: Nobel Yayın Dağıtım.

Stephen, M. (1997). The Cyprus Question. London: The British - Northern Cyprus Parliamentary Group.

Strauss, A. ve Corbin, J. (1990). Basics of Qualitative Research: Grounded Theory Procedures and Techniques. New Delhi: SAGE Publications.

TDK, Türk Dil Kurumu (2011). Genel Türkçe Sözlük, Erişim Tarihi: 18 Aralık 2020 http://www.sozluk.gov.tr.

Tezel, A. (2008). Kuzey Kıbrıs Türk Cumhuriyeti'nin Devlet Olarak Kıbrıs Sorununun Çözümüne Etkisi, Yüksek Lisans Tezi, Kadir Has Üniversitesi Sosyal Bilimler Enstitüsü, İstanbul.

Türk, B. H. (2003). İdeoloji Siyaset içinde Der Mümtazer Türköne. Ankara: Lotus Yayınevi.

Vatansever, M. (2010). Kıbrıs Sorununun Tarihi Gelişimi, Dokuz Eylül Üniversitesi Hukuk Fakültesi Dergisi. s.1487-1530 (Basım Yılı: 2012), Erişimi Tarihi: 22 Temmuz 2020 http://hukuk.deu.edu.tr/dosyalar/dergiler/dergimiz-12ozel/3-kamu/9-mugevatansever.pdf. 


\section{MEDIAJ}

Vural, i. (2010). Televizyon Dünyasının Habercileri Bile (Yaman Bir Paradoks). İstanbul: Derin Yayınları.

Yaylagül, L. ve Çiçek, C. (2012). 12 Haziran 2011 Seçimlerinin Gazetelerde Sunumu, Kayseri, Erciyes iletişim Dergisi, Sayı, 4.

Yeni Şafak., (2017) Rum kesiminin yeni provokasyonu: Enosis kutlamaları. Erişim Tarihi: 15 Mart 2020 http://www.yenisafak.com/dunya/rum-kesiminin-yeniprovokasyonu-enosiskutlamalar

Yıldııım, A. ve Şimşek, H. (2011). Sosyal Bilimlerde Nitel Araştırma Yöntemleri. Ankara: Seçkin Yayınları.

Zizek S. (1994). Mapping Ideology. London: Verso. 